Article

\title{
Thermoeconomic Modelling and Parametric Study of a Simple ORC for the Recovery of Waste Heat in a 2 MW Gas Engine under Different Working Fluids
}

\author{
Guillermo Valencia Ochoa ${ }^{1, * \mathbb{C}}$, Carlos Acevedo Peñaloza ${ }^{2}$ and Jhan Piero Rojas ${ }^{2}$ \\ 1 Programa de Ingeniería Mecánica, Universidad del Atlántico, Carrera 30 Número 8-49, Puerto Colombia, \\ Barranquilla 080007, Colombia \\ 2 Facultad de Ingeniería, Universidad Francisco de Paula Santander, Avenida Gran Colombia No. 12E-96, \\ Cúcuta 540003, Colombia; carloshumbertoap@ufps.edu.co (C.A.P.); jhanpierorojas@ufps.edu.co (J.P.R.) \\ * Correspondence: guillermoevalencia@mail.uniatlantico.edu.co; Tel.: +575-324-94-31
}

Received: 5 September 2019; Accepted: 22 October 2019; Published: 25 October 2019

\begin{abstract}
This paper presents a thermo-economic analysis of a simple organic Rankine cycle (SORC) as a waste heat recovery (WHR) systems of a 2 MW stationary gas engine evaluating different working fluids. Initially, a systematic methodology was implemented to select three organic fluids according to environmental and safety criteria, as well as critical system operational conditions. Then, thermodynamic, exergy, and exergo-economic models of the system were developed under certain defined considerations, and a set of parametric studies are presented considering key variables of the system such as pump efficiency, turbine efficiency, pinch point condenser, and evaporator. The results show the influence of these variables on the combined power of the system (gas engine plus ORC), ORC exergetic efficiency, specific fuel consumption ( $\triangle \mathrm{BSFC})$, and exergo indicators such as the payback period (PBP), levelized cost of energy (LCOE), and the specific investment cost (SIC). The results revealed that heat transfer equipment had the highest exergy destruction cost rates representing $81.25 \%$ of the total system cost. On the other hand, sensitivity analyses showed that acetone presented better energetic and exergetic performance when the efficiency of the turbine, evaporator, and condenser pinch point was increased. However, toluene was the fluid with the best results when pump efficiency was increased. In terms of the cost of exergy destroyed by equipment, the results revealed that acetone was the working fluid that positively impacted cost reduction when pump efficiency was improved; and toluene, when turbine efficiency was increased. Finally, the evaporator and condenser pinch point increased all the economic indicators of the system. In this sense, the working fluid with the best performance in economic terms was acetone, when the efficiency of the turbine, pinch condenser, and pinch evaporator was enhanced.
\end{abstract}

Keywords: energy analysis; exergy analysis; organic Rankine cycle; waste heat recovery; natural gas engine

\section{Introduction}

In recent decades, the dependence on fossil fuel consumption in the energy generation process has increased [1], leading to several difficulties, including the depletion of global energy resources [2] and environmental pollution [3]. Therefore, two routes have been proposed to overcome this issue; the first one is the development and use of renewable energy sources $[4,5]$ and the second one is the development of energetic alternatives to improve energy conversion systems [6,7].

The studies reveal that more than $50 \%$ of the energy used in the world is released by heat [8], and among the different systems that present a high level of waste energy by heat are the internal 
combustion engines (ICE) [9]. These energy conversion systems have been extensively studied to increase efficiency, reduce fuel consumption, and decrease environmental impact $[9,10]$. In this sense, the organic Rankine cycle (ORC) has emerged as one of the most promising technologies for exhaust gas heat recovery in ICE [11]. Among its benefits, concerning other recovery systems, are its simple structure, high safety, easy maintenance, and its viability in economic and energetic terms operating with gases at low temperature, of less than $300{ }^{\circ} \mathrm{C}$ [9].

Numerous studies have been carried out on the application of ORC systems in ICE, which has covered working fluid selection methodologies [12-14], exergy and energy analysis [15,16], thermo-economic optimization [17], and comparative analysis of different ORC configurations performance [18]. Regarding the studies on the performance of organic fluids in ORC coupled to ICE, there are those developed by Scaccabarozzi et al. [19], who performed tests with 22 working fluids, such as pure fluids, synthetic refrigerants, and binary mixtures, determining that the use of binary mixtures does not lead to a considerable increase in thermal efficiency compared to pure fluids. Tian et al. [20] performed a techno-economic analysis of a simple ORC coupled to a $235 \mathrm{~kW}$ diesel Internal Combustion Engine (ICE) to evaluate 20 working fluids and obtain both the highest net output power per mass flow unit and thermal efficiency. The results showed that the set of fluids studied, R141b, R123, and R245fa presented high thermal efficiencies and output power. However, this research is restricted only to a thermo-economic analysis and did not consider count exergo-economic indicators. Wang et al. [21] investigated the performances of the ORC system with nine different pure organic working fluids for engine waste heat recovery. The results revealed that R245fa and R245ca are the most environmentally friendly working fluids. Andreasen et al. [22] provided a generic method for ORCs optimization and fluid selection considering pure fluids and mixtures. It was shown that mixed working fluid can increase the net power output of the cycle.

On the other hand, as far as studies of simple ORC systems in ICE from an exergetic and energetic standpoint, there are those made by Seyedkavoosi et al. [23], which through a parametric study analyzed the effect of operational conditions on the energy and exergy performance of the system using three working fluids. The researchers found that R-123 was the best-performing fluid under established conditions with a net power of $468 \mathrm{~kW}$ and an exergetic efficiency of $21 \%$. Likewise, Yang et al. [24] carried out a thermo-economic optimization of an ORC system in an engine of marine applications considering four organic fluids, and found that the R245fa presented a better performance in economic terms; however, the thermal efficiency of the R1234ze was greater with respect to the other fluids evaluated. Also, the researchers added that the proposed ORC system can reduce the $76 \%$ of $\mathrm{CO}_{2}$ emissions per kilowatt-hour compared with conventional diesel oil feeding.

In the same year, Yang et al. [25] developed a numerical study for a thermo-economic optimization of an ORC to recover heat from the exhaust gases of a marine diesel engine considering five working fluids, where the R1234yf presented the best techno-economic performance, but the results only apply for this specific case engine and cannot be applied to the gas engine consider in this paper. Also, Marami et al. [26] investigated different ORC configurations in a stationary gas engine of $34.4 \mathrm{~kW}$ for exhaust gas recovery using three working fluids from an exergo-economic perspective. The authors found that toluene was the working fluid with the best results for all the configurations in study, from an energy and economic focus; the last through the specific investment cost (SIC). In the study done by Quoilin et al. [27], the specific investment cost (SIC) of the ORC system for waste heat recovery was conducted to seek the optimal working conditions for the economic optimization using R123, R134a, R1234yf, R245fa, R600, R601, SES36, and HFE7000; it was reported that R600 was the optimal working fluid with a specific cost (SIC) of $2136 € / \mathrm{kW}$ and a net power of $4.2 \mathrm{~kW}$.

Imran et al. [28] carried out a thermo-economic optimization of basic ORC and regenerative ORC for waste heat recovery using five different working fluids. Thermal efficiency and specific investment cost (SIC) were considered by using NSGA-II (nondominated sorting genetic algorithm-II). They found that R245fa was the best working fluid under considered conditions with a SIC the $187 \$ / \mathrm{kW}$. Zhang et al. [29] presented the parameter optimization of the subcritical and supercritical ORCs to 
minimize the levelized cost of energy (LCOE) and heat exchanger area per unit power output (APR). They found that R123 yielded maximal thermal efficiency and exergy efficiency in subcritical ORC. Also, the LCOE was studied by Feng et al. [30] employing a multi-objective optimization by using a non-dominated sorting genetic algorithm (NSGA-II). They determined that the LCE of the ORC system was $21.1 \%$ higher than the BORC system under considered conditions. Thus, the authors found the function that minimized the transfer area and the LCOE but without considering an exergetic parameter, they do not present the decision variables of the NSGA-II method, which provide a detailed vision of the research contribution. Finally, Le at al. [31] carried out the thermodynamic and economic optimization of a subcritical ORC using a pure or zeotropic mixture working fluids. They found that the n-pentane was the best fluid with an LCOE of $0.0863 \$ \mathrm{USD} / \mathrm{kWh}$ and a payback period (PBP) of 16.37 years. In this work, they found the optimal values of the thermoeconomic indicators, however there is no explanation about the high value of the PBP, which represents a very long period for economic retribution.

From the literature reviews, and based on recent revisions [9], there is an evidence of the limited availability of exploratory studies concerning the recovery heat from exhaust gases using simple ORC cycles in stationary natural gas engines for power generation. In this sense, the main contribution of this research is to present a parametric analysis of the thermos-economic performance of an ORC integrated into a gas engine under real operation condition, taking four thermos-economic indicators.

From the state of the art presented, it can be concluded that the use of ORC for the generation of energy from a source of residual heat at low gas temperatures $\left(<300^{\circ} \mathrm{C}\right)$ is technically and economically viable, which has allowed its presence in the market since the beginning of the 1980s; especially in applications of biomass, geothermal, and solar solutions in a wide range of power and temperature levels. However, there are still aspects that limit the growth of the technology when integrated with internal combustion engines with exhaust gases at medium temperature $\left(230^{\circ} \mathrm{C}\right.$ to $\left.650{ }^{\circ} \mathrm{C}\right)$, including both the economy of scale of the process and the skepticism of some of the main plant managers when integrating a solution with high PBP and LCOE. Added to this is the neglect of waste heat recovery in engines by both governments and key industry decision-makers. These problems persist to date and hinder the widespread acceptance of ORC technology in industrial generation systems. Thus, this research pursues the modeling and thermo-economic study of one of the most common configurations in the industry as it is, the simple ORC; this analyzes the behavior of the system integrated to a $2 \mathrm{MW}$ natural gas MCI with different working fluids to evaluate the impact of the different operating conditions of the cycle integrated to the generation engine. This system is modeled and validated in different load conditions widely used in the industrial sector, in order to improve the thermo-economic viability of this ORC technology for this thermal source.

\section{Methodology}

\subsection{Description of the SORC System}

Exhaust gases are recovered from a Jenbacher JMS 612 GS-N engine, which is located in an industrial plant for the transformation of plastic packaging in Barranquilla-Colombia. The engine operates with natural gas as fuel with a flow rate of $120 \mathrm{~L} / \mathrm{min}$ at a pressure of $116.36 \mathrm{kPa}$, and a temperature of $38.9^{\circ} \mathrm{C}$ by mean of an ORC configuration. The engine operates at $1482 \mathrm{rpm}$ in island mode, with a mechanical power of $1758.77 \mathrm{~kW}$, where the exhaust gases generated by the engine are in a temperature of $435.1{ }^{\circ} \mathrm{C}$, pressure of $102.30 \mathrm{kPa}$, and mass flow of $2.77 \mathrm{~kg} / \mathrm{s}$. The integration of the SORC system with the gas engine allows one to increase the overall thermal efficiency of the prime mover, as a consequence of the thermal load reduction transferred to the environment, which mean better use of energy [32] as shown in Figure 1. 

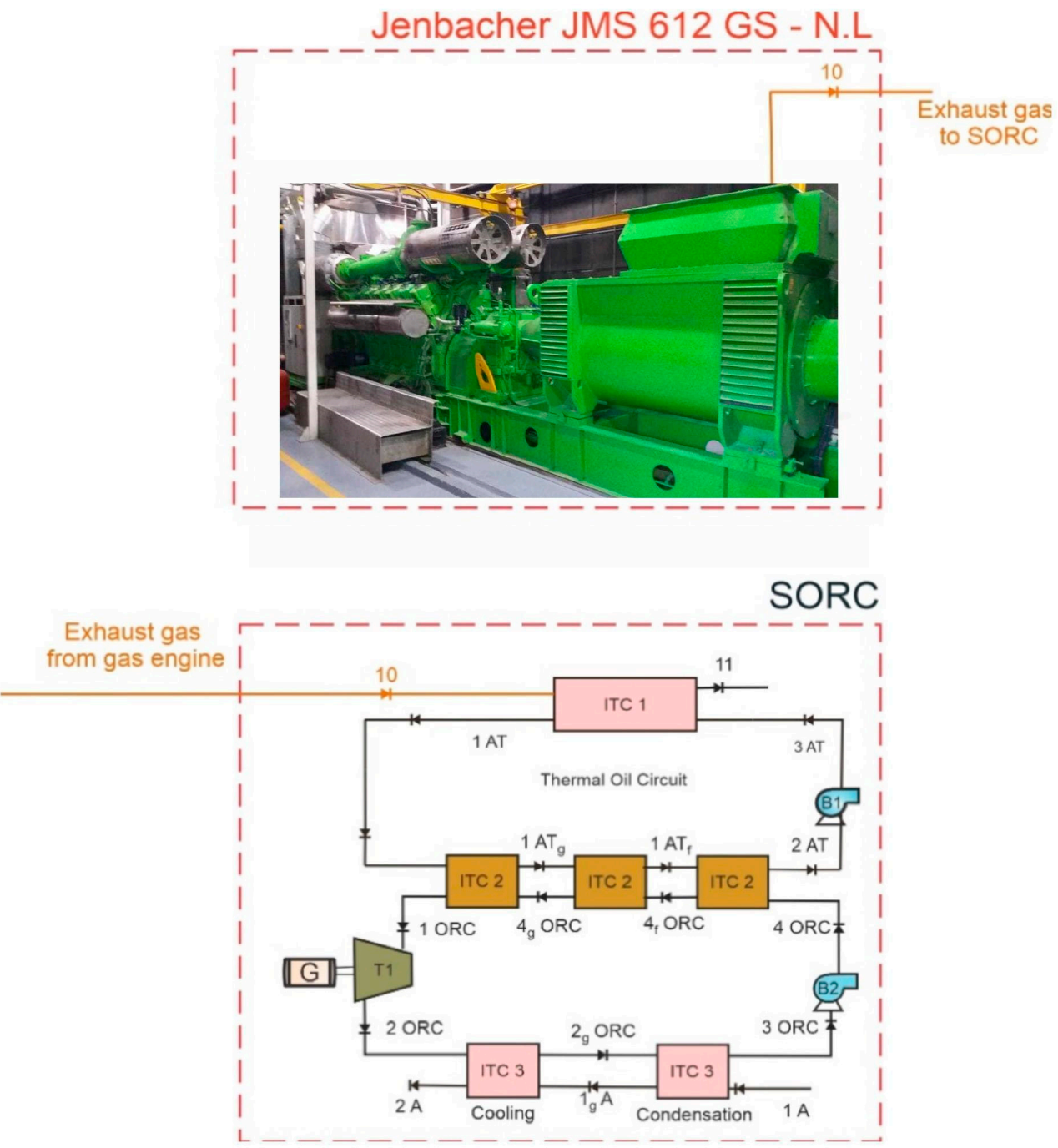

Figure 1. Physical structure of the waste heat recovery (WHR) system coupled with a natural gas engine.

Basically, the physical structure of the system shown in Figure 1 is constituted as follows: The exhaust gases from the natural gas engine (state 10) transfer energy by heat with the thermal oil in the shell and tube heat exchanger (ITC1), and subsequently are evacuated to the environment (state 11). The thermal oil at high pressure (state 3 AT) circulates through the thermal oil circuit through the energy supplied by the Pump 1 (B1) and allows the indirect evaporation of the organic fluid to avoid an unsafe operating temperature in the ORC system. The hot thermal oil (stream 1AT) serves as a thermal source to evaporate the organic fluid in the compact plate heat exchanger (ITC2) to obtain steam superheated (state 1 ORC), which is the highest pressure and temperature of the ORC. Therefore, in this thermodynamic state of the cycle, the fluid is used to convert the thermal energy to electric power through the turbine (T1). The thermal process in the ITC2 is carried out in three zones, named preheating (Zone 1), evaporation (Zone 2), and overheating (Zone 3). As the organic fluid in the turbine (T1) from the evaporator (ITC2) expands, an energy conversion process occurs in the generator (G). The expansion of the fluid is given until the lowest pressure of the cycle to the condenser (ITC3), where all the mass is condensed (state 3 ORC). The condensation process happens in two phases, called condensation process (from state $1 \mathrm{~A}$ to state $1 \mathrm{gA}$ ), and cooling process (state $1 \mathrm{gA}$ to state $2 \mathrm{~A}$ ). Then, the organic fluid pressure is elevated to the evaporating pressure in the ITC2 exchanger with the pump (B2), completing the SORC cycle $[18,31,33,34]$. 


\subsection{Working Fluids Selection}

There is a trade-off between the thermodynamic specification, economic aspects, and environmental limits to select ORC working fluid [35]. The selection of a working fluid delimits the thermal efficiencies of the cycle and the heat recovered from the exhaust gas of the engine, and there is not a defined criterion for the working fluid selection [36,37]. Therefore, a systematic methodology has been proposed as a guide, taking into account chemical characteristics such as thermal stability, molecular weight, critical conditions, and safety and environmental features.

Only the Alkanes have been considered for their favorable critical conditions at high temperatures [38], and they are environmentally friendly, as well as Siloxanes. Chloro Fluoro Carbons (CFCs), and Hydro Chloro Fluoro Carbons (HCFCs) were not considered as candidates due to their effects on the environment according to the Montreal Protocol [39]. Likewise, Hydro Fluoro Carbons (HFCs) were excluded according to the Kyoto protocol [40].

From the criteria presented, the methodology proposed to select the organic working fluid at high operating temperatures is shown in Figure 2. The application of these methodology allows the identification of a group of fluids under particular operational conditions of the process.

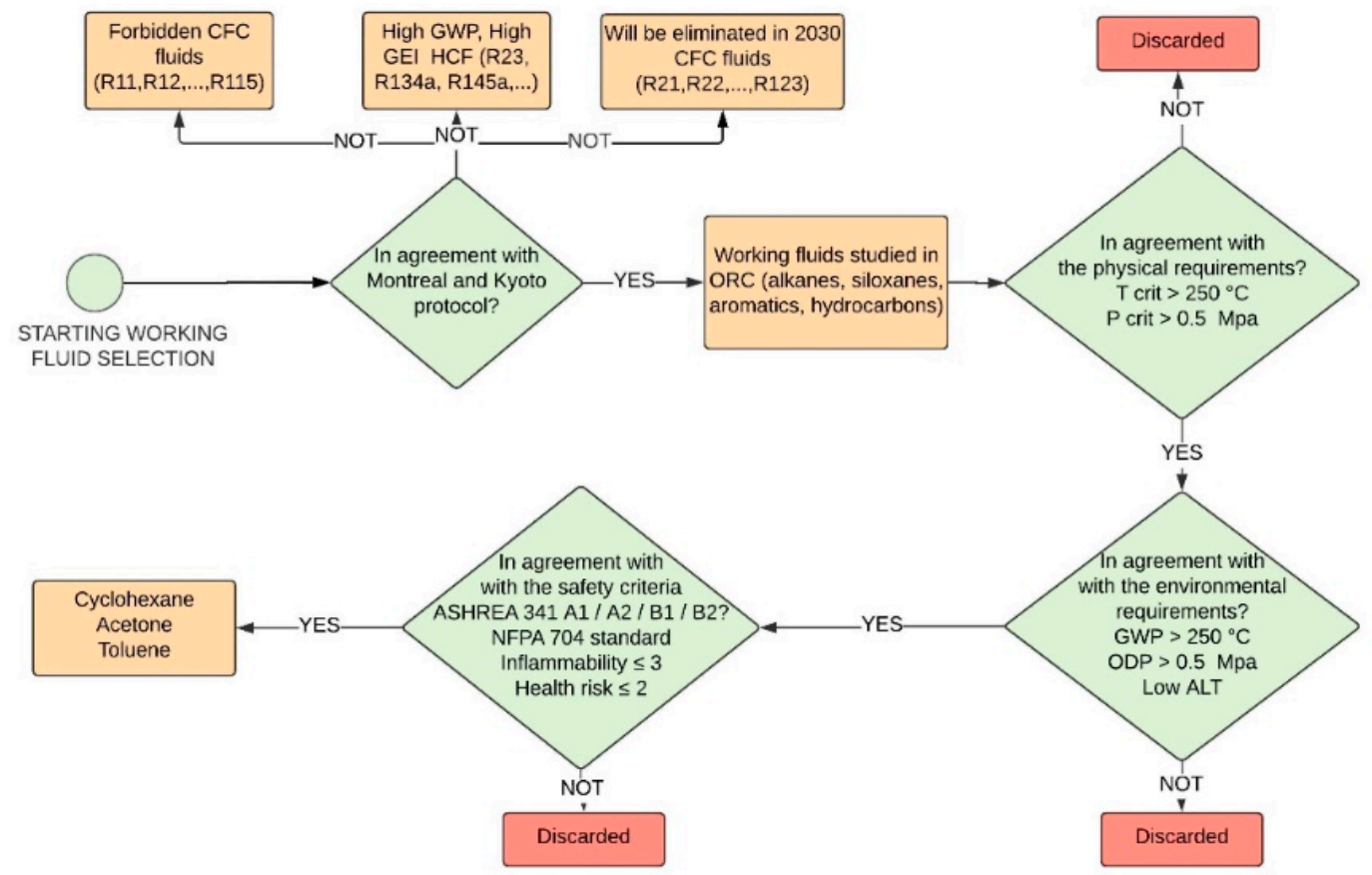

Figure 2. Methodology of working fluids selection.

Additionally, Table 1 presents some recent works, focused on the study of different fluids in ORC systems in $\mathrm{MCI}$, where the presence of alkane groups, alkane cycles, and alcohols in high-temperature applications can be highlighted.

Table 1. Review of organic Rankine cycle (ORC) coupled to Internal Combustion Engine (ICE).

\begin{tabular}{|c|c|c|c|c|}
\hline Year & Engine & $\operatorname{Temp}\left[{ }^{\circ} \mathrm{C}\right]$ & Working Fluids & Reference \\
\hline 2015 & Diesel & 519 & Methanol ${ }^{\mathrm{a}}$, Toluene & [41] \\
\hline 2015 & Diesel & 275-300 & Cyclohexane a , Benzene, Toluene & [42] \\
\hline 2016 & Diesel & 473.2 & Toluene a , Acetone, Benzene, Dichlorohexane & [43] \\
\hline 2016 & Diesel & $212.5-581$ & Acetone a , Ethanol, D4, MDM, MM, MD2M, Glycol & [44] \\
\hline 2016 & Diesel & 373 & n-Pentane ${ }^{a}$, n-Hexane & [45] \\
\hline 2017 & Diesel & $466.8-484.5$ & Acetone ${ }^{\mathrm{a}}$, n-Octane, n-Hexane, MDM, Toluene & [46] \\
\hline
\end{tabular}

${ }^{a}$ Working Fluids that presented a high performance in the system 
There is not an ideal fluid that fulfills all these criteria, but the aim is to select the best one for this particular application. Therefore, following the methodology shown in Figure 2, the acetone, toluene, and cyclohexane, which are dry and isentropic fluids with a high critical temperature, have been chosen as working fluids of ORC to be studied in this work, because of the low global warming potential (GWP) and low ozone depletion potential (ODP), to figure out environmental limits. The physical, chemical, and environmental properties of the selected fluids are presented in Table 2.

Table 2. Physical, chemical, and environmental properties of the selected fluids.

\begin{tabular}{|c|c|c|c|c|c|c|c|c|c|}
\hline \multirow[b]{2}{*}{$\begin{array}{l}\text { Working } \\
\text { Fluid }\end{array}$} & \multirow[b]{2}{*}{ Type } & \multirow[b]{2}{*}{$\begin{array}{c}\text { M } \\
{[\mathrm{kg} / \mathrm{kmol}]}\end{array}$} & \multirow[b]{2}{*}{$\begin{array}{c}\mathbf{P}_{\text {crit }} \\
{[\mathrm{kPa}]}\end{array}$} & \multirow[b]{2}{*}{$\begin{array}{l}\mathrm{T}_{\text {crit }} \\
{\left[{ }^{\circ} \mathrm{C}\right]}\end{array}$} & \multicolumn{2}{|c|}{ NFPA 704} & \multirow[b]{2}{*}{$\begin{array}{l}\text { ALT } \\
{[y r]}\end{array}$} & \multirow[b]{2}{*}{ ODP } & \multirow[b]{2}{*}{ GWP } \\
\hline & & & & & Flammability & $\begin{array}{l}\text { Health } \\
\text { Hazard }\end{array}$ & & & \\
\hline Requirement & Dry/Isentropic & High & $>200$ & $>250$ & $\leq 3$ & $\leq 2$ & $\leq 5$ & 0 & $<2000$ \\
\hline Cyclohexane & Dry & 86.18 & 3060 & 235 & 3 & 2 & - & 0 & Low \\
\hline Toluene & Dry & 92.14 & 4130 & 319 & 3 & 2 & 0.007 & 0 & 2.7 \\
\hline Acetone & Isentropic & 58.08 & 3780 & 235 & 3 & 2 & - & 0 & 0.5 \\
\hline
\end{tabular}

\section{Thermodynamic Modeling and Assumptions}

To simplify the thermodynamic model of the cycle, some assumptions were considered, such as [47]:

- $\quad$ Pressure drops in pipelines are neglected.

- Pressure drops in heat exchangers are calculated as a function of the equipment geometry and the hydraulic flow characteristics.

- $\quad$ All the waste heat recovery (WHR)-ORC components of the cycle are thermally insulated.

- The thermal oil circuit absorbs temperature variations in exhaust gases to obtain steady-state operation in each ORC configuration.

- The exhaust gas was considered as an ideal gas with a chemical composition of $16 \% \mathrm{CO}_{2}, 5.37 \%$ $\mathrm{H}_{2} \mathrm{O}, 73.03 \% \mathrm{~N}_{2}$, and $6.49 \% \mathrm{O}_{2}$.

A simulation program with the energy and exergy analyses was developed in MATLAB R2018b, and the thermodynamic properties of the fluids were calculated with REFPROP 9.0. Appendix A shows the detailed equations of exergy balances applied to SORC configuration.

\subsection{Energy Analysis}

Each component of the ORC studied was considered as an open system in a stable state condition, satisfying the mass balance shown in Equation (1), and the energy balance (Equation (2)).

$$
\begin{gathered}
\sum \dot{\mathrm{m}}_{\text {in }}-\sum \dot{\mathrm{m}}_{\text {out }}=0 \\
\sum \dot{\mathrm{m}}_{\text {in }} \mathrm{h}_{\text {in }}-\sum \dot{\mathrm{m}}_{\text {out }} \mathrm{h}_{\text {out }}+\sum \dot{\mathrm{Q}}-\sum \dot{\mathrm{W}}=0
\end{gathered}
$$

where $\dot{m}$ is the mass flow rate, $h$ is the fluid specific enthalpy, and $\dot{Q}$ and $\dot{W}$ are the energy transfer by heat and work. The energy balance equations for each component is presented in Table 3 , and the thermodynamic model was validated obtaining an error is below to $3 \%$ for R-11 [48].

Likewise, the absolute increase in thermal efficiency is calculated using Equation (3), which is the relation between the net power generated by the engine and the ORC, and the energy supplied by the fuel in the gas engine. This indicator measures the improvement in the gas engine thermal performance in any operation condition integrated with the WHR system.

$$
\eta_{\text {thermic }}=\frac{\dot{\mathrm{W}}_{\text {net }}}{\dot{\mathrm{m}}_{\text {fuel }} \cdot \mathrm{LHV}}
$$


The additional electric power with the WHR system, with respect to the engine power, imply a reduction on the specific fuel consumption (BSFC), which is calculated according to Equation (4) [49].

$$
\mathrm{BSFC}_{\text {ORC-engine }}=\frac{\mathrm{m}_{\text {fuel }}}{\dot{\mathrm{W}}_{\text {engine }}+\dot{\mathrm{W}}_{\text {net }}}
$$

Also, the absolute decrease in the BSFC is calculated with Equation (5) and is an indicator of the fuel economy for the particular operating conditions of the gas engine.

$$
\mathrm{BSFC}=\left(\frac{\left|\mathrm{BSFC}_{\mathrm{ORC}-\text { engine }}-\mathrm{BSFC}_{\text {engine }}\right|}{\mathrm{BSFC}_{\text {engine }}}\right) 100
$$

\begin{tabular}{|c|c|c|c|}
\hline Component & SORC & Component & SORC \\
\hline $\begin{array}{l}\text { Heat Exchanger } \\
\text { (ITC1) }\end{array}$ & $\begin{array}{l}\dot{\mathrm{Q}}_{\mathrm{G}}=\dot{\mathrm{m}}_{10} \mathrm{C}_{\mathrm{P} 10}\left(\mathrm{~T}_{10}-\mathrm{T}_{11}\right) \\
=\dot{\mathrm{m}}_{\mathrm{AT}} \mathrm{C}_{\mathrm{PAT}}\left(\mathrm{T}_{4 \mathrm{AT}}-\mathrm{T}_{3 \mathrm{AT}}\right)\end{array}$ & Turbine 1 (T1) & $\begin{array}{c}\eta_{\mathrm{T} 1}=\frac{\mathrm{h}_{1 \mathrm{ORC}}-\mathrm{h}_{2 \mathrm{ORC}}}{\mathrm{h}_{1 \mathrm{ORC}}-\mathrm{h}_{2 \mathrm{SORC}}} \\
(4 \mathrm{~A} .7) \\
\dot{\mathrm{W}}_{\mathrm{T} 1}=\dot{\mathrm{m}}_{\mathrm{ORC}}\left(\mathrm{h}_{1 \mathrm{ORC}}-\mathrm{h}_{2 \mathrm{ORC}}\right) \\
\text { Zone } \mathrm{E}(\text { Cooling })\end{array}$ \\
\hline Pump 1 (B1) & $\begin{array}{c}\eta_{\mathrm{B} 1}=\frac{v_{2 \mathrm{AT}}\left(\mathrm{P}_{3 \mathrm{AT}}-\mathrm{P}_{2 \mathrm{AT}}\right)}{\mathrm{h}_{3 \mathrm{AT}}-\mathrm{h}_{2 \mathrm{AT}}} \\
\dot{\mathrm{W}}_{\mathrm{B} 1}=\dot{\mathrm{m}}_{\mathrm{AT}}\left(\mathrm{h}_{3 \mathrm{AT}}-\mathrm{h}_{2 \mathrm{AT}}\right)\end{array}$ & $\begin{array}{l}\text { Heat Exchanger } \\
\text { (ITC3) }\end{array}$ & $\begin{aligned} \dot{\mathrm{Q}}_{\mathrm{ZE}}= & \dot{\mathrm{m}}_{\mathrm{ORC}}\left(\mathrm{h}_{2 \mathrm{ORC}}-\mathrm{h}_{2 \mathrm{gORC}}\right) \\
= & \dot{\mathrm{m}}_{1 \mathrm{~A}}\left(\mathrm{~h}_{2 \mathrm{~A}}-\mathrm{h}_{1 \mathrm{gA}}\right) \\
& \text { Zone C }(\text { Condenser }) \\
\dot{\mathrm{Q}}_{\mathrm{ZC}} & =\dot{\mathrm{m}}_{\mathrm{ZC}}\left(\mathrm{h}_{2 \mathrm{gORC}}-\mathrm{h}_{3 \mathrm{ORC}}\right) \\
& =\dot{\mathrm{m}}_{1 \mathrm{~A}}\left(\mathrm{~h}_{1 \mathrm{gA}}-\mathrm{h}_{1 \mathrm{~A}}\right)\end{aligned}$ \\
\hline $\begin{array}{l}\text { Heat Exchanger } \\
2 \text { (ITC2) }\end{array}$ & $\begin{array}{c}\text { Zone } 1 \text { (Preheating) } \\
\dot{\mathrm{Q}}_{\mathrm{Z} 1}=\dot{\mathrm{m}}_{\mathrm{AT}}\left(\mathrm{h}_{\mathrm{ATf}}-\mathrm{h}_{\mathrm{ATT}}\right) \\
=\dot{\mathrm{m}}_{\mathrm{ORC}}\left(\mathrm{h}_{4 \mathrm{fORC}}-\mathrm{h}_{4 \mathrm{ORC}}\right) \\
\text { Zone } 2(\text { Evaporation }) \\
\dot{\mathrm{Q}}_{\mathrm{Z} 2}=\dot{\mathrm{m}}_{\mathrm{AT}}\left(\mathrm{h}_{\mathrm{ATg}}-\mathrm{h}_{\mathrm{ATf}}\right) \\
=\dot{\mathrm{m}}_{\mathrm{Z} 2}\left(\mathrm{~h}_{\mathrm{fgORC}}\right) \\
\text { Zone } 3(\text { overheating }) \\
\dot{\mathrm{Q}}_{\mathrm{Z} 3}=\dot{\mathrm{m}}_{\mathrm{AT}}\left(\mathrm{h}_{1 \mathrm{AT}}-\mathrm{h}_{\mathrm{ATg}}\right) \\
=\dot{\mathrm{m}}_{\mathrm{ORC}}\left(\mathrm{h}_{1 \mathrm{ORC}}-\mathrm{h}_{4 \mathrm{gORC}}\right)\end{array}$ & Pump 2 (B2) & $\begin{array}{c}\eta_{\mathrm{B} 2}=\frac{v_{3 \mathrm{ORC}}\left(\mathrm{P}_{4 \mathrm{ORC}}-\mathrm{P}_{3 \mathrm{ORC}}\right)}{\mathrm{h}_{4 \mathrm{ORC}}-\mathrm{h}_{3 \mathrm{ORC}}} \\
\left(\dot{\mathrm{W}}_{\mathrm{B} 2}=\dot{\mathrm{m}}_{\mathrm{ORC}}\left(\mathrm{h}_{4 \mathrm{ORC}}-\mathrm{h}_{3 \mathrm{ORC}}\right)\right.\end{array}$ \\
\hline
\end{tabular}

Table 3. Energy balances for the components of simple organic Rankine cycle (SORC) configuration.

\subsection{Exergo-Economic Analysis}

\subsubsection{Economic Analysis}

To estimate the total production cost (TPC) of the WHR systems, the total capital invested (TCI) and the operation and maintenance costs (O\&M) are considered, as shown in Equation (6) [50].

$$
\mathrm{TPC}=\mathrm{TCI}+\mathrm{O} \& M
$$

where the TCI of the SORC systems is calculated by means of Equation (7) [51].

$$
\mathrm{TCI}=\mathrm{FCI}+\text { other costs }
$$

where the fixed cost investment $(\mathrm{FCI})$ of the system is a function of the direct cost $(\mathrm{CD})$ and indirect costs (CI), according to Equation (8).

$$
\mathrm{FCI}=\mathrm{CD}+\mathrm{CI}
$$

In addition, the other costs (SUC) are related to the start-up costs of the devices, the initial working capital of the thermal system (WC), the costs related to the research and development actions (LRD), 
and the costs related to the provision of resources in the construction phase (AFUDC), as shown in in Equation (9).

$$
\text { Other } \cos \mathrm{ts}=\mathrm{SUC}+\mathrm{WC}+\mathrm{LRD}+\mathrm{AFUDC}
$$

The purchase cost of the heat exchangers (evaporator and condenser), the pump, and the turbine used correlations depending on the output power of the turbine, the power of the pump, and the area of the heat exchanger, considering commercial data from manufacturers [52-54]. The purchase cost equation for the turbine is given by Equation (10) [52,54,55].

$$
\log _{10} \mathrm{Z}=2.6259+1.4398 \cdot \log _{10} \dot{\mathrm{W}}_{\mathrm{t}}-0.1776 \cdot\left(\log _{10} \dot{\mathrm{W}}_{\mathrm{t}}\right)^{2}
$$

while the heat exchanger used Equation (11) [53,54]

$$
\log _{10} Z=10000+324 \cdot\left(\mathrm{A}^{0.91}\right) .
$$

Finally, the pump cost is calculated through Equation (12) as [52,54].

$$
\log _{10} \mathrm{Z}=3.3892+0.0536 \cdot \log _{10} \dot{\mathrm{W}}_{\mathrm{p}}-0.1538 \cdot\left(\log _{10} \dot{\mathrm{W}}_{\mathrm{p}}\right)^{2}
$$

Because of the capital costs of the equipment decrease along time, while the fuel and O\&M costs increase, the leveled values of these costs are considering the leveling factor constant escalation (CELF) based on Equation (13), which estimate the cost levelized values [51].

$$
\mathrm{CELF}=\mathrm{CRF} \cdot \frac{\mathrm{k} \cdot\left(1-\mathrm{k}^{\mathrm{n}}\right)}{1-\mathrm{k}}
$$

where $\mathrm{n}$ represents the project lifetime, $\mathrm{k}$ is the annual effective cost rate (Equation (14)), and CRF is the return on capital factor (Equation (15)).

$$
\begin{gathered}
k=\frac{1+\mathrm{r}_{\mathrm{n}},}{1+\mathrm{i}_{\text {eff }}} \\
\mathrm{CRF}=\frac{\mathrm{i}_{\mathrm{eff}} \cdot\left(1+\mathrm{i}_{\mathrm{eff}}\right)^{\mathrm{n}}}{\left(1+\mathrm{i}_{\mathrm{eff}}\right)^{\mathrm{n}}-1},
\end{gathered}
$$

where $r_{n}$ is the nominal scaling ratio and $\left(i_{e f f}\right)$ is the annual interest rate. The economic data assumed for the economic and exergo-economic modeling were: Interest rate $\left(i_{e f f}\right) 5 \%$ [29], nominal rate of scaling $\left(r_{n}\right) 5 \%$ [25], project time (n) 20 years [31], hours of annual operation $(\tau) 7446$ [29].

\subsubsection{Cost Balance}

The SPECO method applied in this research is based on three main stages [51]. In the initial stage, the exergy of each flow is determined, and a detail flow diagram of the system is developed presenting the exergy value of the inputs and outputs stream as a result of the exergy balance. In the second stage, the exergy performance of each component is studied as a function of the different flow interacting in the boundary of the device. Subsequently, in the last stage, the cost balances equations are proposed, as shown for this case in Table 4 . The exergy cost of the k-device is the addition of the capital investment $\left(\dot{\mathrm{Z}}_{\mathrm{k}}^{\mathrm{CI}}\right)$ and the O\&M costs $\left(\dot{\mathrm{Z}}_{\mathrm{k}}^{\mathrm{OM}}\right)$, as shown in Equation (16).

$$
\dot{\mathrm{Z}}_{\mathrm{K}}=\dot{\mathrm{Z}}_{\mathrm{k}}^{\mathrm{CI}}+\dot{\mathrm{Z}}_{\mathrm{k}}^{\mathrm{OM}}
$$


Table 4. Exergetic cost balances of system components.

\begin{tabular}{|c|c|c|c|}
\hline Component & SORC & Component & SORC \\
\hline ITC1 & $\begin{array}{c}\mathrm{c}_{10}\left(\dot{\mathrm{E}}_{\mathrm{x} 11}-\dot{\mathrm{E}}_{\mathrm{x} 10}\right)- \\
\mathrm{c}_{1 \mathrm{AT}} \dot{\mathrm{E}}_{\mathrm{x} 1 \mathrm{AT}}= \\
\mathrm{c}_{3 \mathrm{AT}} \dot{\mathrm{E}}_{\mathrm{x} 3 \mathrm{AT}}+\dot{\mathrm{Z}}_{I T C 1}\end{array}$ & $\mathrm{~T} 1$ & $\begin{array}{c}c_{1 O R C}\left(\dot{E}_{x 2 O R C}-\dot{E}_{x 1 O R C}\right)+ \\
c_{W T 1} \dot{W}_{T 1}=\dot{Z}_{T 1} \\
c_{1 O R C}=c_{2 O R C}\end{array}$ \\
\hline B1 & $\begin{array}{c}\mathrm{c}_{3 \mathrm{AT}} \dot{\mathrm{E}}_{\mathrm{x} 3 \mathrm{AT}}=\mathrm{c}_{2 \mathrm{AT}} \dot{\mathrm{E}}_{\mathrm{x} 2 \mathrm{AT}}+ \\
\mathrm{c}_{\mathrm{WT} 1} \dot{\mathrm{W}}_{\mathrm{B} 1}+\dot{\mathrm{Z}}_{\mathrm{B} 1} \\
\mathrm{c}_{\mathrm{WB} 1}=\mathrm{c}_{\mathrm{WT} 1}\end{array}$ & ITC3 & $\begin{array}{c}c_{1 O R C}\left(\dot{E}_{x 3 O R C}-\dot{E}_{x 2 O R C}\right) c_{2 A} \dot{E}_{2 A}= \\
\dot{Z}_{I T C 3} \\
c_{1 A}=0\end{array}$ \\
\hline ITC2 & $\begin{array}{c}\mathrm{c}_{1 \mathrm{AT}}\left(\dot{\mathrm{E}}_{\mathrm{x} 2 \mathrm{AT}}-\dot{\mathrm{E}}_{\mathrm{x} 1 \mathrm{AT}}\right)+ \\
\mathrm{c}_{1 \mathrm{ORC}} \dot{\mathrm{E}}_{\mathrm{x} 1 \mathrm{ORC}}= \\
\mathrm{c}_{4 \mathrm{ORC}} \dot{\mathrm{E}}_{\mathrm{x} 4 \mathrm{ORC}}+\dot{\mathrm{Z}}_{\mathrm{ITC} 2} \\
\mathrm{c}_{1 \mathrm{AT}}=\mathrm{c}_{2 \mathrm{AT}}\end{array}$ & B2 & $\begin{array}{c}c_{4 O R C} \dot{E}_{x 4 O R C}= \\
c_{4 O R C} \dot{E}_{x 3 O R C}+c_{W T 1} \dot{W}_{B 2}+\dot{Z}_{B 2} \\
c_{W B 2}=c_{W T 1}\end{array}$ \\
\hline
\end{tabular}

The exergy costs balance applied to open systems under a steady-state operation condition follow the structure presented in Equation (17). [54].

$$
\sum_{j=1}^{n} \dot{C}_{j, k, \text { in }}+\dot{Z}_{K}=\sum_{j=1}^{m} \dot{C}_{j, k, \text { out }}
$$

The exergetic balances equations for the devices of the SORC systems employing Equation (17) are presented in detail in Table 4.

The total exergy cost flow can be defined as shown in Equation (18).

$$
\dot{\mathrm{C}}_{\mathrm{j}}=\mathrm{c}_{\mathrm{j}} \cdot \dot{\mathrm{E}}_{\mathrm{j}}
$$

The term $c_{j}$ is the levelized cost per unit of exergy. In the ITC1 and ITC 3 of the SORC system, the costs per unit of exergy of state 11 and state $1 \mathrm{~A}$ are null, because they have negligible acquisition and selling costs.

\subsubsection{Cost of Destroyed Exergy and Lost Exergy}

The destroyed exergy cost rate (Equation (19)) and lost exergy cost rate (Equation (20)) are indispensable values to develop the thermo-economic study of the WHR system. The destroyed exergy cost rate of a device is not contemplated in the cost balances, which is the reason because it is related to an unknown cost [56]. In these balances, an average input cost with a variable quantity of exergy destruction or exergy loss is supposed.

$$
\begin{aligned}
& \dot{\mathrm{C}}_{\mathrm{D}, \mathrm{K}}=\mathrm{c}_{\mathrm{I}, \mathrm{k}} \dot{\mathrm{E}}_{\mathrm{D}, \mathrm{k}} \\
& \dot{\mathrm{C}}_{\mathrm{L}, \mathrm{K}}=\mathrm{c}_{\mathrm{I}, \mathrm{k}} \dot{\mathrm{E}}_{\mathrm{L}, \mathrm{k}}
\end{aligned}
$$

For the $\mathrm{k}$ device of the WHR system, the cost related to the input flow is estimated by using Equation (21), and the cost of the product using Equation (22).

$$
\begin{array}{r}
\mathrm{c}_{\mathrm{I}, \mathrm{K}}=\frac{\dot{\mathrm{C}}_{\mathrm{I}, \mathrm{K}}}{\dot{\mathrm{E}}_{\mathrm{I}, \mathrm{K}}} \\
\mathrm{c}_{\mathrm{P}, \mathrm{K}}=\frac{\dot{\mathrm{C}}_{\mathrm{P}, \mathrm{K}}}{\dot{\mathrm{E}}_{\mathrm{P}, \mathrm{K}}}
\end{array}
$$




\subsection{Thermoeconomic Performance Indicators}

The cost increase between $c_{\mathrm{I}, \mathrm{K}}$ and $\mathrm{c}_{\mathrm{P}, \mathrm{K}}$ is caused by the cost of exergy destruction and the investment related cost $\left(\dot{Z}_{k}\right)$ as the relative cost different $\left(r_{K}\right)$ [57], and determines the increase in the unit cost of exergy between the product and the input relative to the unit cost of the input [56], calculated by Equation (23).

$$
\mathrm{r}_{\mathrm{K}}=\frac{\mathrm{c}_{\mathrm{P}, \mathrm{k}}-\mathrm{c}_{\mathrm{I}, \mathrm{k}}}{\mathrm{c}_{\mathrm{I}, \mathrm{k}}} \text {. }
$$

The exergo-economic factor $\mathrm{f}_{\mathrm{K}}$ compares the two cost sources contributing to the cost increase between and shows the contribution of the investment-related cost to the sum of the cost of exergy destruction and investment-related cost [57].

$$
\mathrm{f}_{\mathrm{K}}=\frac{\dot{\mathrm{Z}}_{\mathrm{k}}}{\dot{\mathrm{Z}}_{\mathrm{k}}+\mathrm{c}_{\mathrm{F}, \mathrm{k}} \cdot\left(\dot{\mathrm{E}}_{\mathrm{D}, \mathrm{k}}+\dot{\mathrm{E}}_{\mathrm{L}, \mathrm{k}}\right)}
$$

The levelized cost of energy (LCOE) [29] is defined as the system cost to total net power output, which is selected as the evaluation criterion for economic factors, according to Equation (25).

$$
L C O E=\frac{\sum_{n=0}^{\mathrm{N}}\left(C_{n}+O \& M_{n}+F E_{n}\right)}{\sum_{n=0}^{\mathrm{N}} \frac{E_{n}}{(1+r)^{n}}}
$$

Another indicator is the specific investment cost (SIC), defined as the relationship between the investment cost and the net power generated, according to Equation (26).

$$
\mathrm{SIC}_{\mathrm{ORC}}=\frac{\mathrm{C}_{\mathrm{ORC}}}{\mathrm{W}_{\mathrm{T}}-\mathrm{W}_{\mathrm{P}}}
$$

Finally, the payback period is the time required, after start-up, for the annual earnings to equal the original investment. Because it is simple and even more understandable than simple return on investment (ROI), PBP is widely used in early evaluations to compare alternative [58] and is calculated by Equation (27).

$$
\mathrm{PBP}=\frac{\mathrm{C}_{\mathrm{TDC}}}{(1-\mathrm{t})\left(\mathrm{S}_{\text {annual }}-\mathrm{C}_{\mathrm{TPC}}\right)+\mathrm{C}_{\mathrm{D}}}
$$

\section{Results and Discussions}

A comparative parametric study has been carried out to investigate the effect of turbine efficiency, pump efficiency, Pinch evaporator, and Pinch condenser on the energy, exergetic, and economic indicators of the SORC operating with different working fluids. The simulation was developed in MATLAB ${ }^{\circledR}$. The main reference values for the SORC system using the three working fluids are shown in Table 5.

Table 5. Parameters considered for the proposed configuration.

\begin{tabular}{lccc}
\hline Parameter & Value & Units & Reference \\
\hline Isentropic efficiency turbines & 80 & $\%$ & {$[59]$} \\
Isentropic efficiency pump & 75 & $\%$ & {$[59]$} \\
Cooling water temperature (1 AT) & 50 & ${ }^{\circ} \mathrm{C}$ & \\
Pinch Point condenser (ITC3) & 15 & ${ }^{\circ} \mathrm{C}$ & \\
Pinch Point evaporator (ITC2) & 35 & ${ }^{\circ} \mathrm{C}$ & \\
Pressure Ratio B1 & 2.5 & & \\
Pressure Ratio B2 & 30 & & \\
\hline
\end{tabular}


The main physical and chemical properties of the process streams are presented in Table 6 for the Acetone, and in the Appendix A are presented the thermodynamic properties for the toluene (Table A1) and cyclohexane (Table A2). Their cost rates and leveled cost per unit of exergy using Acetone as the working fluid can be observed. Because the exergy for some SORC system streams is the same, the changes presented in the cost rates for these streams are due to the different values taken by the specific exergy cost.

Table 6. Thermodynamic properties and cost rate for SORC with Acetone.

\begin{tabular}{cccccccc}
\hline Stream & $\begin{array}{c}\mathbf{F} \\
{[\mathbf{k g} / \mathbf{s}]}\end{array}$ & $\begin{array}{c}\mathbf{T} \\
{\left[{ }^{\circ} \mathbf{C}\right]}\end{array}$ & $\begin{array}{c}\mathbf{P} \\
{[\mathbf{k P a}]}\end{array}$ & $\begin{array}{c}\mathbf{h} \\
{[\mathbf{k J} / \mathbf{k g}]}\end{array}$ & $\begin{array}{c}\mathbf{E} \\
{[\mathbf{k W}]}\end{array}$ & $\begin{array}{c}\dot{\mathbf{C}} \\
{\left[\mathbf{1 0}^{-\mathbf{3}} \mathbf{U S D} / \mathbf{s}\right]}\end{array}$ & $\begin{array}{c}\boldsymbol{c} \\
{[\mathbf{U S D} / \mathbf{G}]}\end{array}$ \\
\hline 10 & 2.77 & 435.071 & 102.30 & -1960.35 & 541.20 & 2.16 & 3.99 \\
11 & 2.77 & 270 & 101.30 & -2143.67 & 296.45 & 0.00 & 0.00 \\
$1 \mathrm{AT}$ & 1.64 & 305.43 & 101.43 & 456.13 & 207.12 & 1.86 & 8.98 \\
$1 \mathrm{ATg}$ & 1.64 & 210.061 & 91.27 & 247.82 & 61.92 & 0.56 & 8.98 \\
1 ATf & 1.64 & 176.96 & 80.67 & 180.58 & 29.16 & 0.26 & 8.98 \\
2 AT & 1.64 & 140.24 & 68.15 & 109.36 & 5.42 & 0.055 & 8.98 \\
3 AT & 1.64 & 140.36 & 170.38 & 109.59 & 5.48 & 0.15 & 26.53 \\
1 ORC & 0.72 & 270.43 & 4086.31 & 781.66 & 178.19 & 2.71 & 15.22 \\
2 ORC & 0.72 & 136.082 & 136.21 & 626.87 & 52.33 & 0.80 & 15.22 \\
2 gORC & 0.72 & 65 & 136.21 & 511.47 & 37.61 & 0.57 & 15.22 \\
3 ORC & 0.72 & 65 & 136.21 & 20.053 & 2.88 & 0.04 & 15.22 \\
4 ORC & 0.72 & 67.083 & 4086.31 & 27.16 & 6.65 & 0.35 & 52.83 \\
4 fORC & 0.72 & 225.61 & 4086.31 & 462.77 & 90.29 & 0.36 & 3.97 \\
4 gORC & 0.72 & 225.61 & 4086.31 & 613.94 & 130.78 & 1.038 & 7.87 \\
1A & 13.32 & 50 & 101.30 & 209.42 & 42.40 & 0.00 & 0.00 \\
1gA & 13.32 & 55 & 101.30 & 230.33 & 65.58 & 0.59 & 8.98 \\
2A & 13.32 & 56.17 & 101.30 & 235.24 & 71.72 & 1.20 & 16.69 \\
\hline
\end{tabular}

\subsection{Thermo-Economic Analysis}

The thermo-economic analysis of the SORC system was performed by calculating the exergy destroyed by equipment, and the input cost, to determine the exergy destruction cost, the exergoeconomic factor, and the relative cost difference per component of the system. Table 7 shows the exergy destruction rates of each of the system components, where the highest exergy destruction rates occur in the ITC1 heat transfer units (shell and tube exchanger), the ITC2 evaporator (plate heat exchanger), and the ITC 3 condenser (plate heat exchanger). The Appendix A shows the thermo-economic data for the toluene (Table A3) and cyclohexane (Table A4).

Table 7. Exergies destroyed by component, exergy destruction costs, difference of relative cost, and exergo-economic factor by a system component (Acetone).

\begin{tabular}{ccccccccc}
\hline Component & $\begin{array}{c}\dot{\mathrm{Ex}}_{\mathrm{D}} \\
{[\mathbf{k W}]}\end{array}$ & $\begin{array}{c}\dot{\mathrm{C}}_{\mathrm{D}} \\
{[\mathrm{USD} / \mathrm{s}]}\end{array}$ & $\begin{array}{c}\dot{\mathrm{C}}_{\mathrm{L}} \\
{[\mathrm{USD} / \mathrm{s}]}\end{array}$ & $\begin{array}{c}\mathrm{Z}_{\mathrm{K}} \\
{[\mathrm{USD} / \mathrm{s}]}\end{array}$ & $r_{K}$ & $f_{K}$ & $\boldsymbol{C}_{\boldsymbol{I}}[\mathrm{USD} / \mathrm{GJ}]$ & $\boldsymbol{C}_{\boldsymbol{P}}[\mathrm{USD} / \mathrm{GJ}]$ \\
\hline ITC1 & 43.10 & 0.38 & 2.61 & $7.38 \cdot 10^{-4}$ & 0.63 & 0.66 & 8.82 & 8.50 \\
B1 & 0.32 & 0.012 & - & $8.08 \cdot 10^{-5}$ & 38.54 & 0.86 & 42.17 & 1667.37 \\
ITC2 & 30.17 & 0.27 & - & $5.50 \cdot 10^{-4}$ & 0.53 & 0.67 & 8.98 & 13.76 \\
T1 & 20.16 & 0.31 & - & $2.54 \cdot 10^{-3}$ & 1.77 & 0.89 & 15.22 & 42.17 \\
ITC3 & 20.14 & 0.82 & 2.93 & $4.44 \cdot 10^{-4}$ & 1.062 & 0.35 & 40.83 & 15.22 \\
B2 & 1.081 & 0.05 & - & $1.03 \cdot 10^{-4}$ & 0.93 & 0.69 & 42.17 & 81.49 \\
\hline
\end{tabular}

These three system components represent $81.25 \%$ of the total destroyed exergy cost of the system, due to the presence of irreversibility in the heat transfer processes that occur inside the device, as a consequence of the temperature differences between the thermal oil and the organic fluid, which leads to increased exergy destroyed. Following is the turbine with a value of $20.16 \mathrm{~kW}(17.53 \%)$, and 
finally, the pumps, representing only $1.22 \%$ of the total cost of exergy destroyed from the system, these equipment being the ones that present low values with respect to the others due to the changes of temperature between the inlet and the outlet that do not exceed $2 \%$.

On the other hand, the exergo-economic factor plays an important role in this type of analysis, since it is a criterion that makes it possible to evaluate the relative importance of the destruction of exergy and capital investment costs. In that sense, the values of the exergo-economic factor greater than 0.5 shown in Table 7 reveal that the operation and maintenance costs are more effective with respect to the exergetic product costs of the system inefficiencies. Therefore, in the case of B1 and T1, which have the highest values of factor $f$ in the cycle, the possibility of acquiring more economical ones by sacrificing the exergetic efficiency of the equipment must be evaluated.

Finally, for all components of the system, a reduction in operation and maintenance costs is suggested to avoid low exergetic efficiencies and high destruction costs. On the other hand, the sum of the $C$ values $\dot{C}_{D}+\dot{C}_{L}+Z_{k}$ is high for ITC1, suggesting a component with an improvement potential from the exergo-economic point of view.

\subsection{Sensitivity Analysis}

3.2.1. Effect of Turbine, Pump, Pinch Condenser, and Evaporator Efficiency on Energy and Exergetic Indicators

Figure 3 shows the effect that the efficiency of the turbine and pump have on the energy and energy indicators of the system, using three working fluids. As for $\triangle \mathrm{BSFC}$, it is observed in Figure $3 \mathrm{a}$, for the percentage of specific fuel consumption savings of the ORC engine assembly with respect to the engine only, that the results reveal that the increase in turbine efficiency from $60 \%$ to $90 \%$ generates an increase of $1.54 \%, 1.99 \%$, and $1.78 \%$ for toluene, acetone, and cyclohexane, respectively. However, the variation in pump efficiency in the same study range does not significantly affect the $\triangle \mathrm{BSFC}$, yielding values of $0.041 \%$ for toluene, $0.0043 \%$ for acetone, and $0.049 \%$ for cyclohexane, according to Figure 3d.
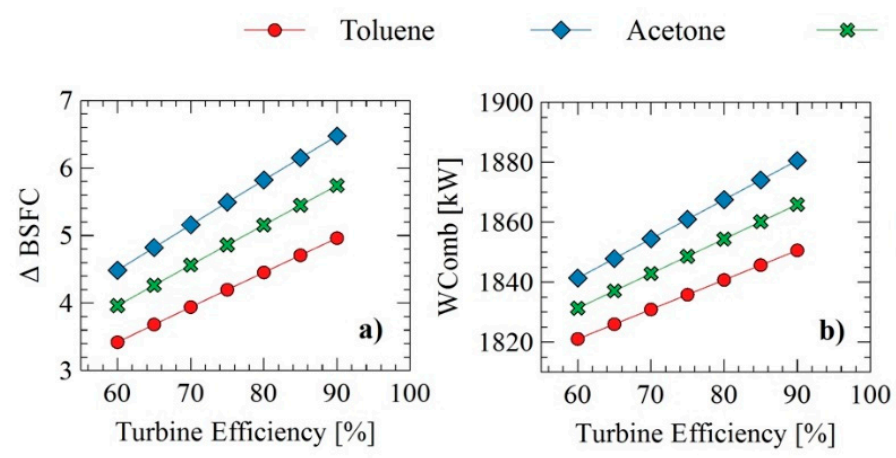

Cyclohexane
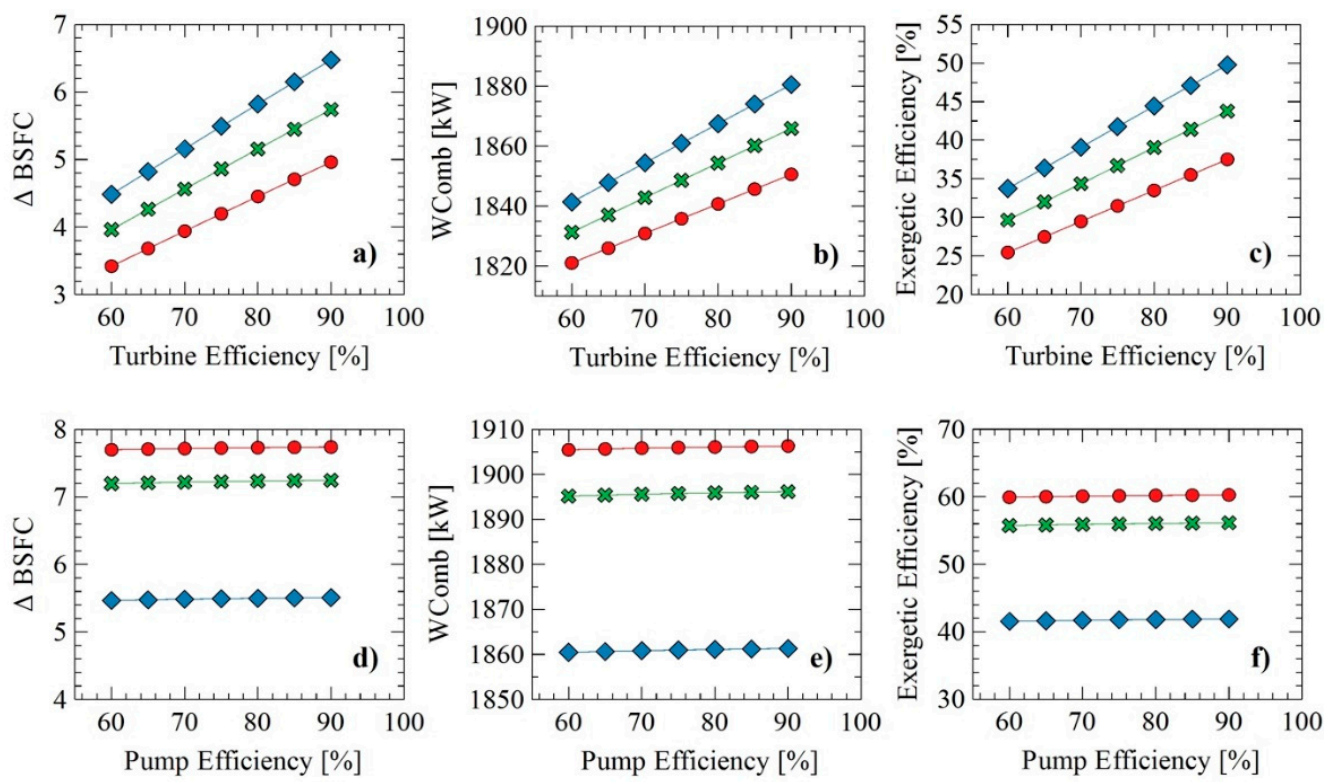

Figure 3. Effect of turbine and pump efficiency variation on (a,d) specific fuel consumption $(\triangle B S F C)$, $(\mathbf{b}, \mathbf{e})$ Wcomb, and (c,f) exergetic efficiency using toluene, acetone, and cyclohexane as working fluids.

Also, it is observed that the increase of the turbine efficiency improves the combined power (gas engine plus ORC) 1.62\% when the working fluid is toluene, $2.13 \%$ with acetone, and $1.89 \%$ for 
cyclohexane, according to Figure $1 \mathrm{~b}$. However, the variation in pump efficiency still presents a slight variation that does not exceed 1\%, as shown in Figure 3e.

On the other hand, in terms of exergetic analysis, the results show that the increase in turbine efficiency in the range of study generates an increase in exergetic efficiency of $47.4 \%$ (toluene), $16.01 \%$ (acetone), and 14.1\% (cyclohexane), as shown in Figure 3c. However, the variation in pump efficiency did not significantly affect the exergetic efficiency, whose behavior was similar when studying the $\triangle B S F C$ and the Wcomb. These results show that the efficiency of the turbine is a variable that significantly affects the energy and exergetic performance of the system, with respect to the efficiency of the pump. However, even though the effect of the pump efficiency does not affect, to a great extent, the outputs of the energetic and exergetic indicators, these present higher values with respect to those reported when the turbine efficiency is varied, according to Figure 3c. Additionally, the most promising working fluid is toluene, compared to acetone, which presented a good performance when increasing the turbine efficiency.

Figure 4 shows the behavior of the $\triangle \mathrm{BSFC}$, Wcomb, and exergetic efficiency of the system as a function of the evaporator and condenser pinch. Figure $4 \mathrm{a}$ shows that the increase of the evaporator pinch causes a slight decrease of $\triangle \mathrm{BSFC}$ of $3.59 \%$ (toluene), $0.05 \%$ (acetone), and $0.16 \%$ (cyclohexane). In addition, when the Pinch condenser is increased, the $\triangle$ BSFC decreases by $0.98 \%$ (toluene), $5.07 \%$ (acetone), and 7.16\% (cyclohexane), as seen in Figure 4d.
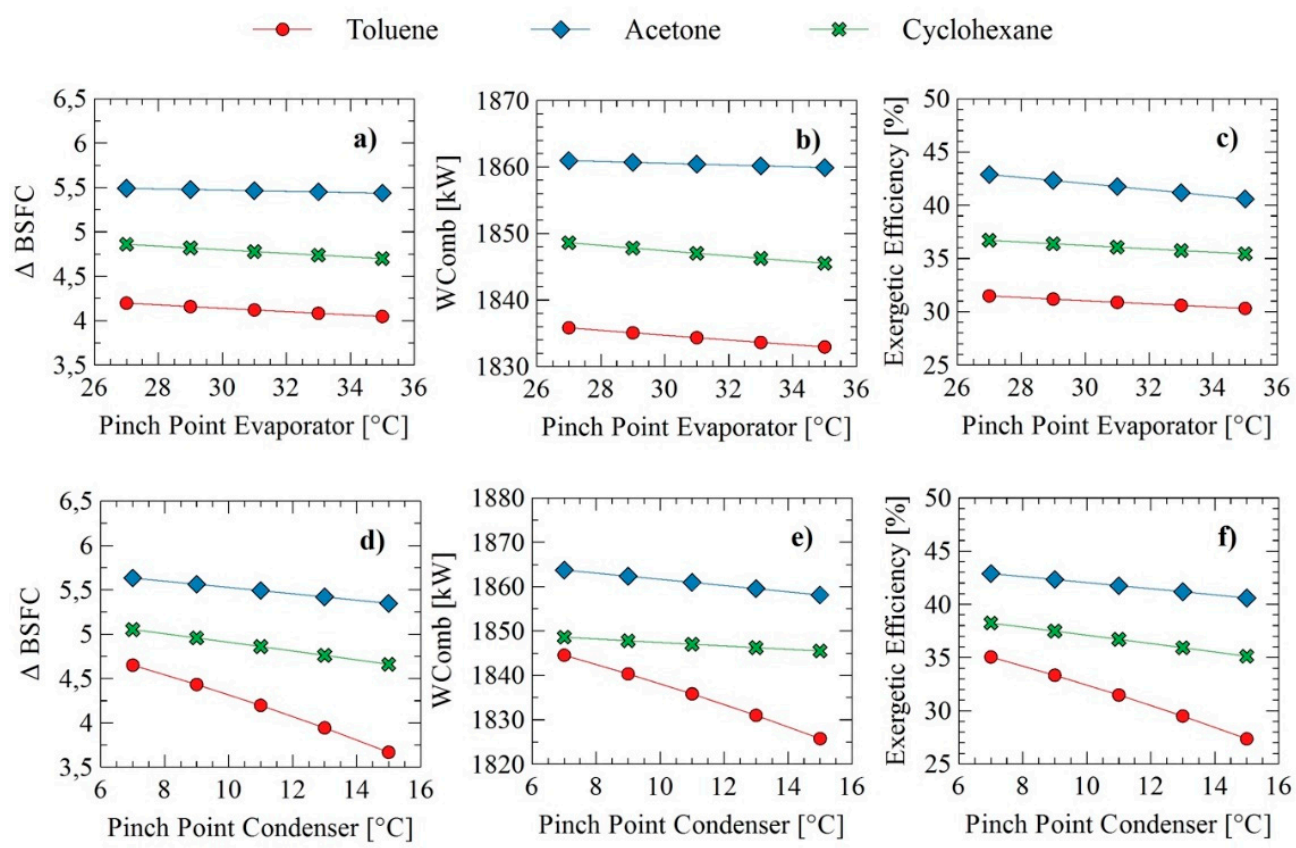

Figure 4. Effect of the evaporator and condenser pinch point on $(\mathbf{a}, \mathbf{d}) \triangle B S F C,(\mathbf{b}, \mathbf{e})$ Wcomb, and $(\mathbf{c}, \mathbf{f})$ exergetic efficiency using toluene, acetone, and cyclohexane as working fluid.

This behavior is similar to that obtained in Figure $4 \mathrm{~b}, \mathrm{e}$, where the increase of the pinch evaporator generates a decrease of the combined power (Wcomb) of 2.88\% (toluene), $0.06 \%$ (acetone), and $0.17 \%$ (cyclohexane) and a decrease of $1.02 \%$ (toluene), $0.30 \%$ (acetone), and $0.41 \%$ (cyclohexane) when the pinch of the condenser is increased. Finally, the exergetic efficiency also decreases when the condenser and evaporator pinch is increased, as a consequence of the lower energy recovery and increase of irreversibilities in this equipment. In this case, the exergetic efficiency of the system tends to decrease more when the pinch of the condenser with toluene is increased with respect to the other fluids. In this sense, acetone was the working fluid that produced the best results compared to toluene and cyclohexane. It also allows for reaching different performances in the system due to its great sensitivity to operational changes. 
3.2.2. Effect of Turbine, Pump, Pinch Condenser, and Evaporator Efficiency on Cost of Exergy Destroyed by Component

The effect that study variables have on the cost of destroyed exergy in each of the system components is shown in Figure 5. Pump efficiency continues to be a study variable that does not significantly affect system indicators.

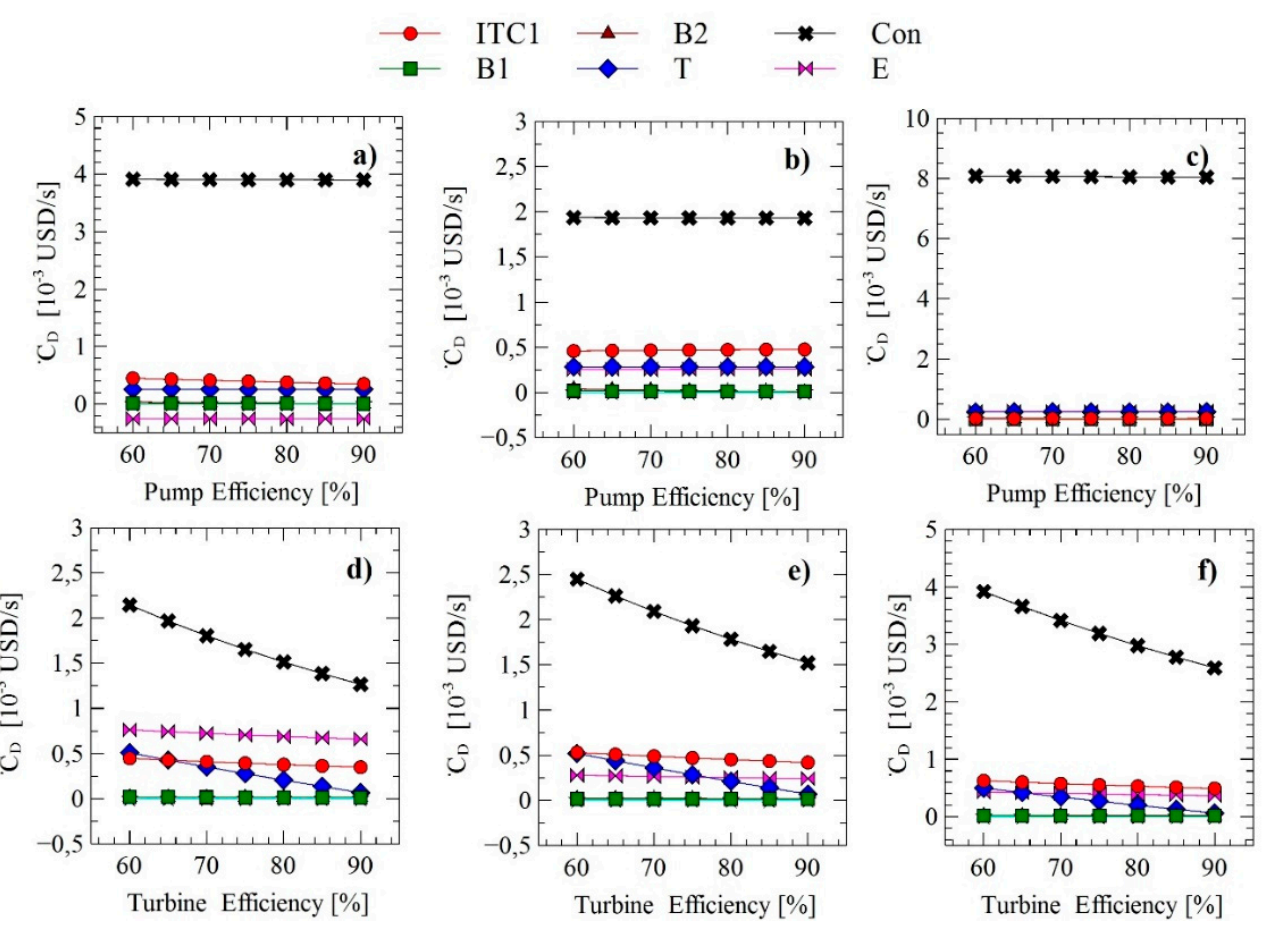

Figure 5. Effect of turbine and pump efficiency on the cost of exergy destroyed by component using as organic working fluids $(\mathbf{a}, \mathbf{d})$ toluene, $(\mathbf{b}, \mathbf{e})$ acetone, $(\mathbf{c}, \mathbf{f})$ cyclohexane.

In this case, Figure $5 \mathrm{a}-\mathrm{c}$ shows a constant trend in the variation of destroyed energy costs of system components as pump efficiency increases. It is also observed that the component with the highest values of the destroyed exergy cost is the condenser, recording values in the range of $3.90 \times 10^{-3} \mathrm{USD} / \mathrm{kWh}$ when the system worked with toluene $1.93 \times 10^{-3} \mathrm{USD} / \mathrm{kWh}$ for acetone and $8.08 \times 10^{-3} \mathrm{USD} / \mathrm{kWh}$ for cyclohexane; while the other components do not vary drastically and remain approximately within the same output ranges when compared to other fluids. However, the pumps do represent a reduction in the cost of exergy destruction, which was in the range of $33.30 \%$ for the thermal oil pump (B1), and $83.33 \%$ for the organic fluid pump (B2), when all three working fluids were used as the isentropic efficiency of the pump increased within the evaluated range. The opposite happens with the increase of the efficiency of the turbine, which results in a significant decrease in the cost of destroyed exergy for the condenser and the turbine. The condenser has a $40.95 \%$ and $86.78 \%$ reduction for the turbine when toluene is used as the working fluid. In addition, the condenser is reduced by $37.88 \%$ and the turbine by $86.83 \%$ using acetone. Finally, when working with cyclohexane, the cost of destroyed exergy is reduced by $33.88 \%$ in the condenser and $87.13 \%$ in the turbine, while for the other components the variation was less, whose decreases do not exceed $22 \%$.

Figure 6 shows the influence of the evaporator pinch and condenser pinch on the costs of exergies destroyed by components. As for the pinch condenser, Figure $6 \mathrm{a}-\mathrm{c}$ reveals that the increase of the temperature pinch of the condenser causes decreases of $32.60 \%$ (toluene), $25.33 \%$ (acetone), and $37.35 \%$ (cyclohexane) in the cost of destruction of exergy in the condenser. The opposite case occurs in the cost of exergy destruction in the evaporator, which increases by $42.97 \%$ (toluene), $12.93 \%$ (acetone), and $32.08 \%$ (cyclohexane). Similar behavior is found in pump 2 (B2), which records increases in the cost of destroyed exergy of $29.69 \%$ (toluene), $30.34 \%$ (acetone), and $30.89 \%$ (cyclohexane). 


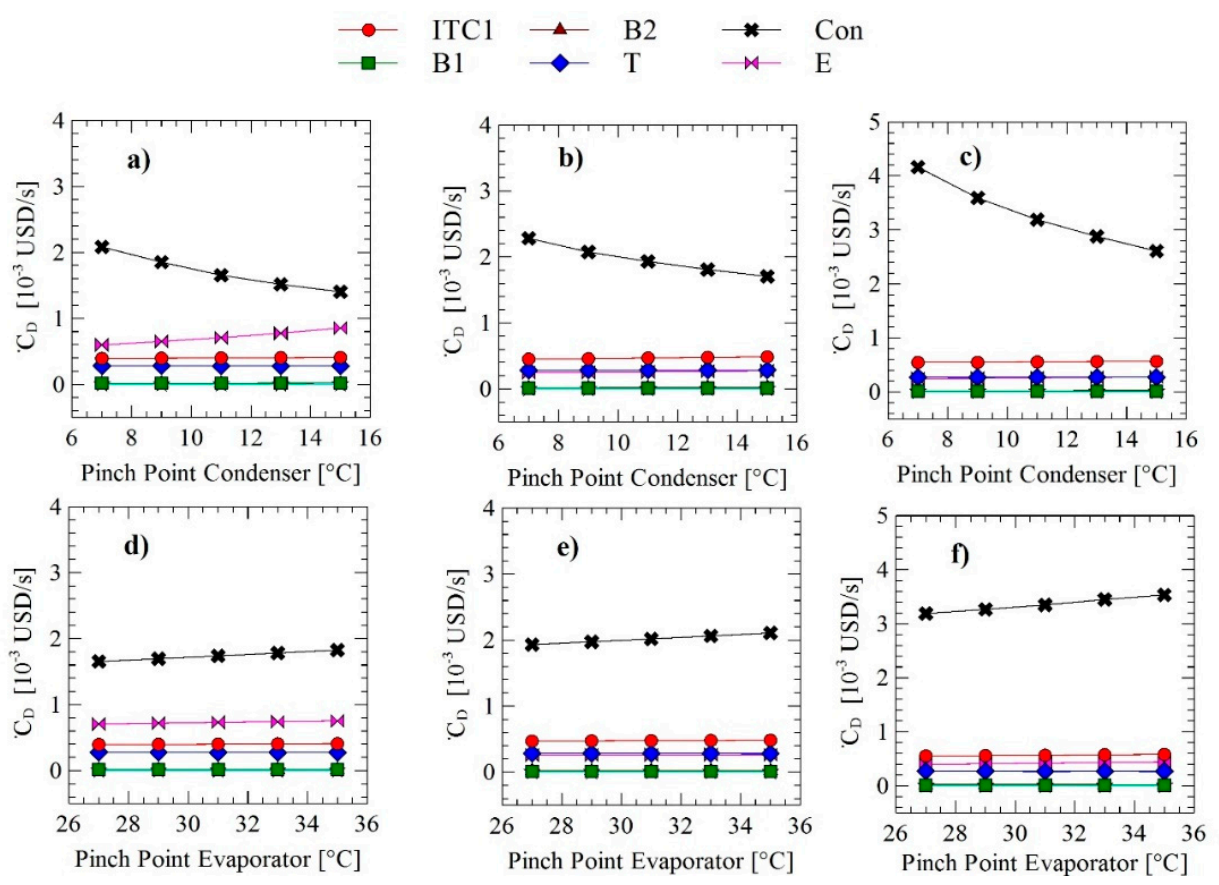

Figure 6. Effect of the condenser and evaporator pinch point on the cost of exergy destroyed using as organic working fluids $(\mathbf{a}, \mathbf{d})$ toluene, $(\mathbf{b}, \mathbf{e})$, acetone, $(\mathbf{c}, \mathbf{f})$ cyclohexane.

The equipment that was least affected by the variation of the pinch condenser was the turbine whose increase did not exceed $1.3 \%$ in the three cases. The other components showed slight increases that did not exceed $15 \%$ when working with toluene, acetone, and cyclohexane. On the other hand, as far as the effect of the increase in the evaporator pinch is concerned, Figure $6 \mathrm{~d}-\mathrm{f}$ shows an increase in the costs of destroying the exergy of the components with the exception of the organic fluid pump (B2), which was the only one to show a slight decrease below $4 \%$ in the three cases, due to the increase in the evaporator pinch temperature. The other components presented increases in the costs of destroyed exergy that did not exceed $10 \%$, which is because, in the evaluated range, there were no important changes in the destroyed exergy of these components

3.2.3. Effect of Turbine, Pump, Pinch Condenser, and Evaporator Efficiency on SORC System Economic Indicators

Figure 7 shows the effect of turbine and pump efficiency on the system indicators, where an increase in turbine efficiency, as shown in Figure $7 \mathrm{a}-\mathrm{c}$, causes a decrease in the three system indicators considered in the study. The LCOE decreases by $21.1 \%$, the SIC by $21.7 \%$, and the PBP by $21.2 \%$ for the three working fluids, which evidences that the efficiency of the turbine in the range of study has a positive impact on lower values of the economic indicators of the system, with acetone being the fluid that presents better results in comparison to toluene and cyclohexane.

On the other hand, the efficiency of the pump did not significantly affect the economic indicators, as shown in Figure $7 \mathrm{~d}-\mathrm{f}$. In this case, the economic indicators did not show a decrease greater than $1 \%$.

However, it is important to consider that although the efficiency of the pump does not exert any significant variation on the economic indicators, they tend to take lower values than those obtained when varying the efficiency of the turbine. In this sense, when the efficiency is $90 \%$ for both the pump and the turbine using toluene as the working fluid, LCOE values of $0.1132 \mathrm{USD} / \mathrm{kWh}$ and $0.1470 \mathrm{USD} / \mathrm{kWh}$, respectively, are obtained. Therefore, it is necessary to perform multi-objective studies to determine the optimal values of the variables of studies to maximize energy indicators by decreasing the economic indicators of the system. 

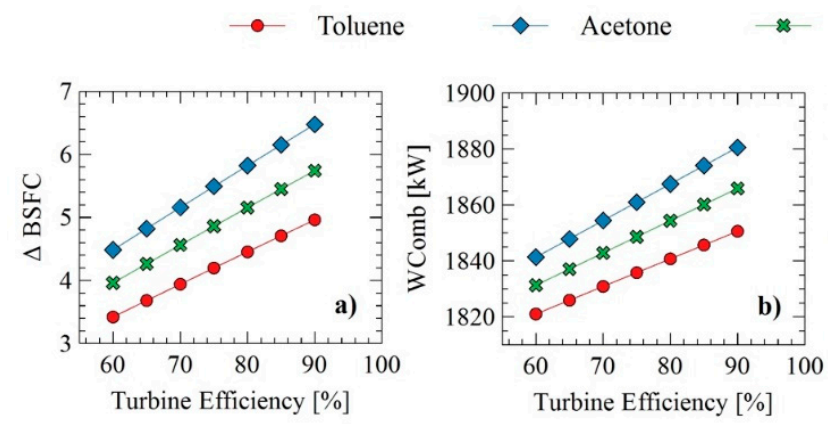

Cyclohexane
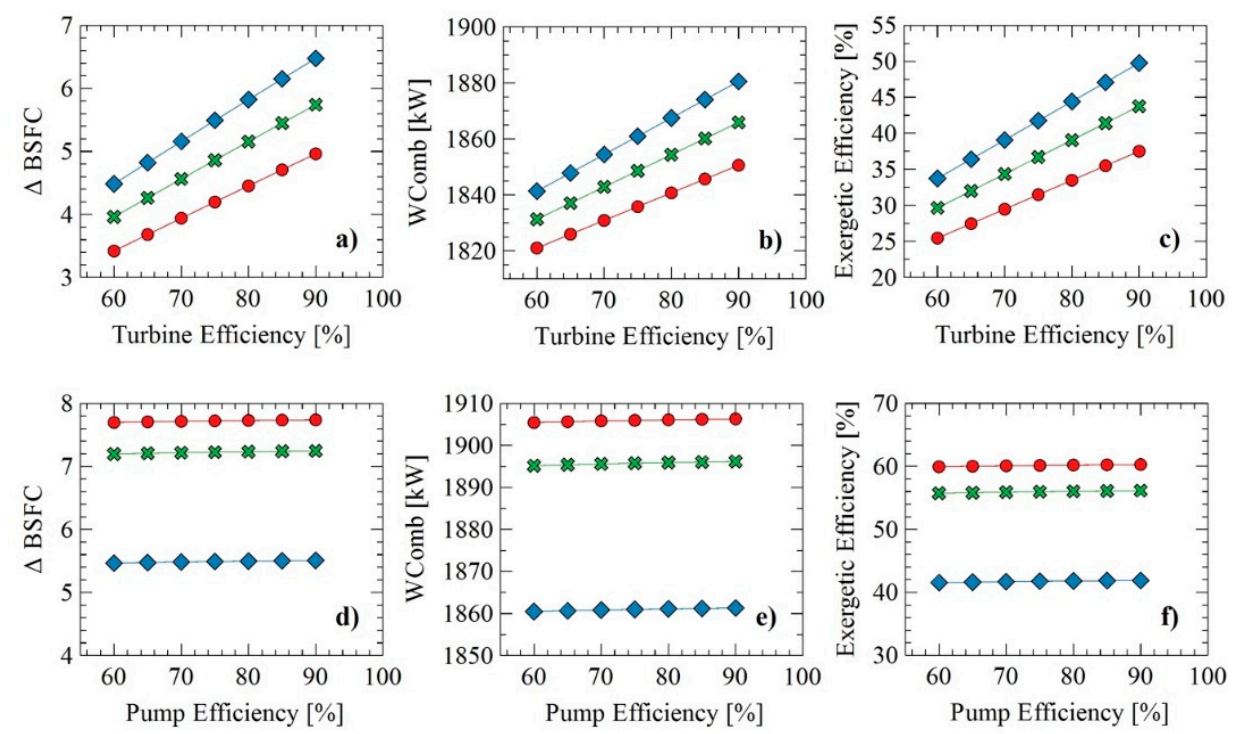

Figure 7. Effect of the turbine and pump efficiency on (a,d) $\triangle B S F C,(\mathbf{b}, \mathbf{e})$ Wcomb, and (c,f) exergetic efficiency using toluene, acetone, and cyclohexane as working fluid.

Figure 8 shows the effect of the increase in evaporator pinch temperature on the values of the system's economic indicators, using toluene, acetone, and cyclohexane as the working fluid. The results show that the increase in the three economic indicators does not exceed $2.5 \%$ for toluene and cyclohexane, while for acetone they were below $1 \%$ as shown in Figure 8a-c. In addition, the temperature of the condenser pinch also influences an increase in the indications of the system as shown in Figure 8d-f, where the LCOE showed an increase of $16.10 \%$ (toluene), 3.64\% (acetone), and 5.86\% (cyclohexane). Similar behavior was found in the SIC and PBP where their output values showed percentages of increase similar to those reported in the LCOE, which is because these indicators are calculated from the same variables of cost-effectiveness of the system.
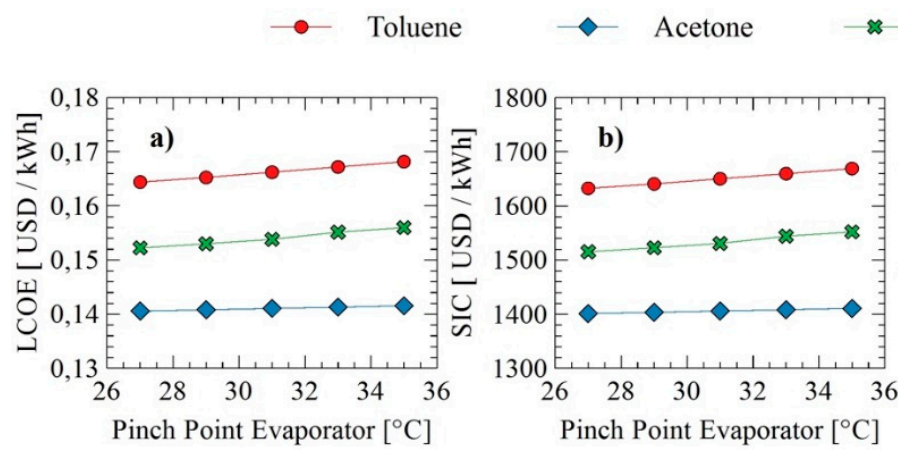

\section{Cyclohexane}
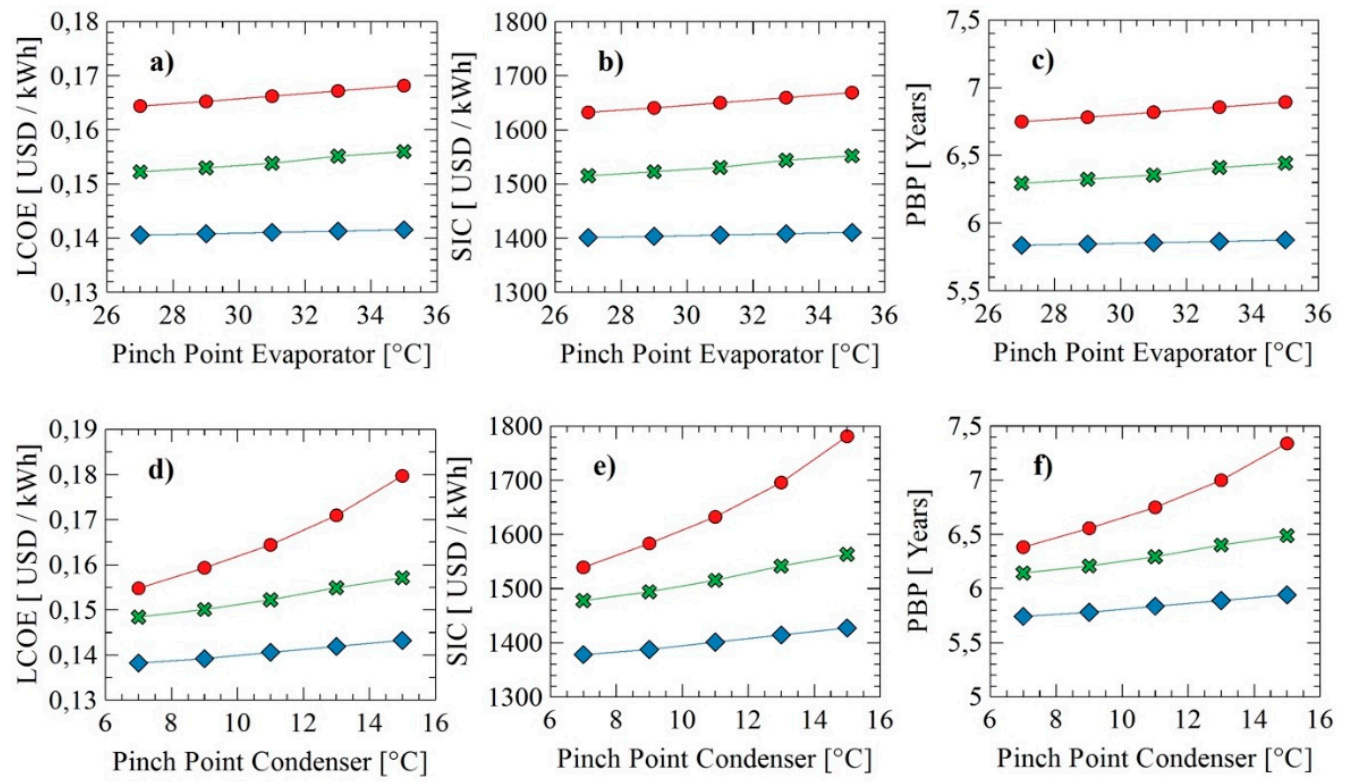

Figure 8. Effect of condenser and evaporator pinch point on $(\mathbf{a}, \mathbf{d})$ LCOE, $(\mathbf{b}, \mathbf{e})$ SIC, and $(\mathbf{c}, \mathbf{f})$ PBP using toluene, acetone, and cyclohexane as working fluid. 


\section{Conclusions}

In this article, a simple Rankine organic cycle (SORC) system has been adapted for exhaust heat recovery in a stationary natural gas power generation engine. Initially, a selection methodology was implemented that allowed the selection of three organic fluids according to safety and environmental criteria, as well as critical system conditions. Then, thermodynamic, exergetic, and economic models of the system were developed under certain defined considerations and, finally, under a set of parametric studies taking into account four variables of the system such as pump efficiency, turbine efficiency, pinch condenser, and pinch evaporator, it was possible to observe the influence that these variables exert on the combined power of the system (Wcomb engine plus ORC), exergetic efficiency, specific fuel consumption ( $\triangle \mathrm{BSFC}$ ), and on the economic indicators (PBP, LCOE, SIC). The main conclusions can be summarized as follows:

As for the thermo-economic analysis of the SORC system, it was found that the highest rates of exergy destruction occur in the heat transfer units ITC1 (tube and shell exchanger), in the evaporator ITC2 (plate exchanger), and in the condenser ITC3 (plate exchanger). These three system components represented $81.25 \%$ of the total destroyed exergy cost of the system. Next was the turbine with a value of $20.16 \mathrm{~kW}(17.53 \%)$, and finally, the pumps represented only $1.22 \%$ of the total cost of exergy destroyed from the system. Also, the exergo-economic factor $\mathrm{f}$ revealed that the B1 and $\mathrm{T} 1$ are the components with the highest values of the system, which implies that the possibility of acquiring more economic ones must be evaluated sacrificing the exergetic efficiency of the equipment. Finally, the sum of the $C$ values $\dot{C}_{D}+\dot{C}_{L}+Z_{k}$ was high for ITC1 compared to the other equipment, suggesting a component with potential for improvement from the exergo-economic point of view.

From the parametric study, it is concluded that the turbine efficiency significantly affected the energetic and exergetic performance of the system, with respect to the pump efficiency. However, even though the effect of the variation of the efficiency of the pump did not affect, to a great extent, the outputs of the energetic and exergetic indicators, these presented higher values than those reported when the turbine efficiency was varied. The opposite case was evidenced when studying the influence of the pinch condenser and pinch evaporator, where the increase of these variables generated a decrease in power (Wcom), specific fuel consumption $(\triangle \mathrm{BSFC})$, and exergetic efficiency of the system. In this section, acetone was the working fluid that produced the best results in terms of energy and exergetic efficiency compared to toluene and cyclohexane.

As for the costs of exergies destroyed by components, the condenser is the device that presented the highest values when the pump efficiency was varied, registering values in the range of $3.90 \times 10^{-3} \mathrm{USD} / \mathrm{kWh}$ when the working fluid is toluene, $1.93 \times 10^{-3} \mathrm{USD} / \mathrm{kWh}$ for acetone, and $8.08 \times 10^{-3} \mathrm{USD} / \mathrm{kWh}$ for cyclohexane, while the other components did not present a significant variation; so, the acetone was the best working fluid in this configuration. In addition, when the turbine efficiency was increased, a decrease in the cost of destroyed exergy was presented in all components, with toluene being the fluid with the best performance. The influence of the evaporator pinch point increase caused a decrease in the cost of destroyed exergy for the condenser, while for the evaporator and pump 2 (B2), it resulted in an increase, with the toluene in this case study being the fluid that gives the lower values. However, the increase of the evaporator pinch generated an increase in the costs of destroyed exergy that did not exceed $10 \%$ in the components, except Pump 2 (B2).

Finally, regarding economic indicators, it is concluded that the increase in the efficiency of the turbine results in a decrease in the three indicators of the system, with acetone being the working fluid with the best results. The efficiency of the pump did not significantly affect the indicators; however, compared to the results obtained with the efficiency of the turbine, these were below, with toluene being the fluid with better performance. On the other hand, the increase of the pinch condenser and evaporator generated an increase in the economic indicators. 
Author Contributions: Conceptualization: G.V.O.; methodology: G.V.O. and C.A.P.; software: G.V.O., J.P.R., and C.A.P.; validation: G.V.O., J.P.R., and C.A.P.; formal Analysis: G.V.O., J.P.R., and C.A.P.; investigation: G.V.O.; resources: G.V.O. and C.A.P.; writing—original draft preparation: G.V.O.; writing—review and editing: J.P.R. and C.A.P.; funding acquisition: G.V.O.

Funding: This work was supported by the Universidad Del Atlántico, Universidad Francisco de Paula Santander and the E2 Energía Eficiente S.A E.S.P company.

Acknowledgments: the authors are grateful to Mr. Rafael Diaz and Mr. Edgardo Castro for his collaboration and technical support received in the thermal oil circuit modelling of the waste heat recovery systems.

Conflicts of Interest: The authors declare no conflict of interest.

\section{Abbreviations}

The following abbreviations are used in this manuscript:

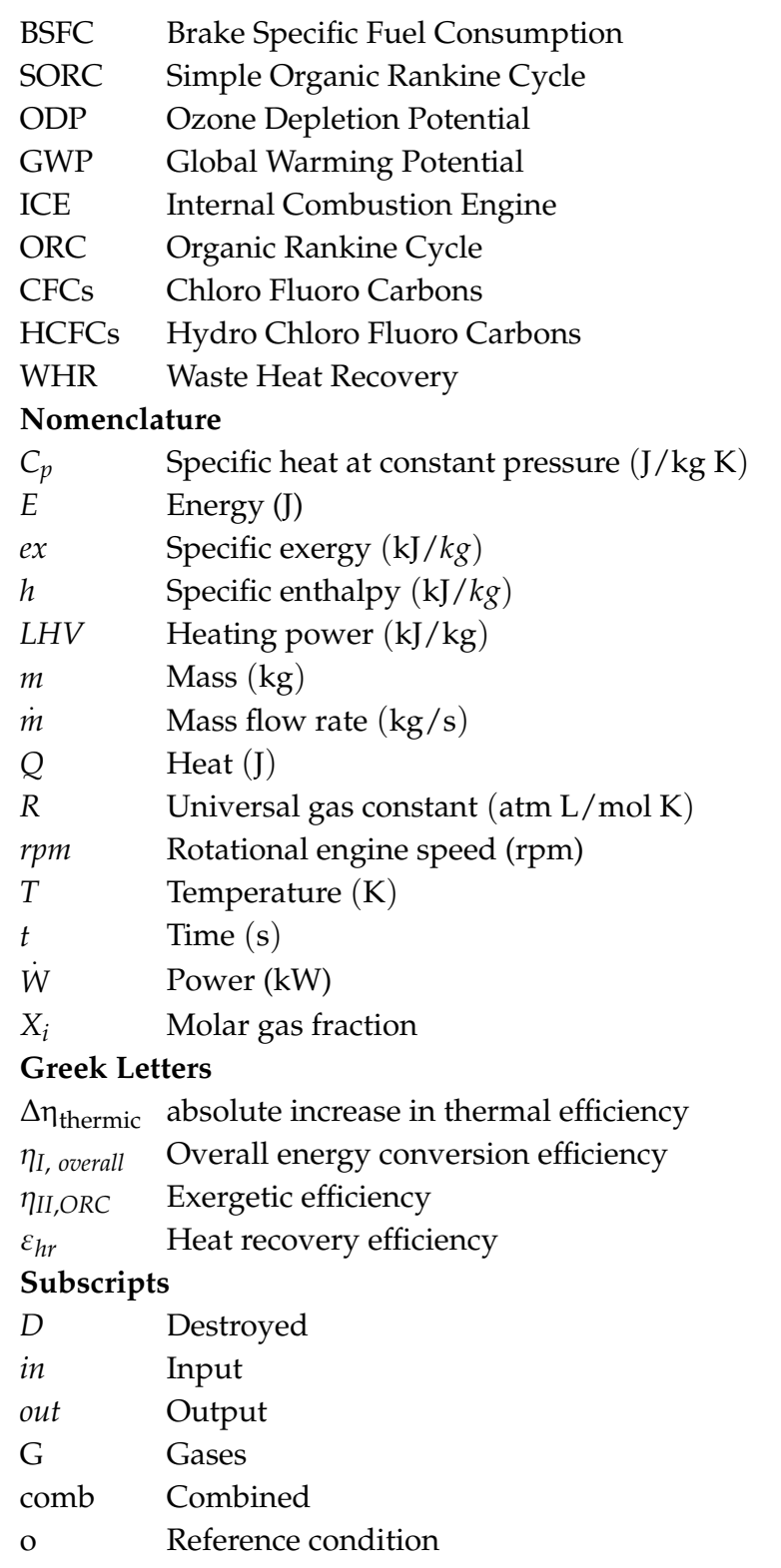




\section{Appendix A}

Table A1. Thermodynamic properties and cost rate at different point using Toluene.

\begin{tabular}{cccccccc}
\hline Stream & $\begin{array}{c}\mathbf{F} \\
{[\mathbf{K g} / \mathbf{s}]}\end{array}$ & $\begin{array}{c}\mathbf{T} \\
{\left[{ }^{\circ} \mathbf{C}\right]}\end{array}$ & $\begin{array}{c}\mathbf{P} \\
{[\mathbf{k P a}]}\end{array}$ & $\begin{array}{c}\mathbf{h} \\
{[\mathbf{k J} / \mathbf{k g}]}\end{array}$ & $\begin{array}{c}\mathbf{E} \\
{[\mathbf{k W}]}\end{array}$ & $\begin{array}{c}\dot{C} \\
{\left[\mathbf{1 0}^{-\mathbf{3}} \mathbf{U S D} / \mathbf{s}\right]}\end{array}$ & $\begin{array}{c}\boldsymbol{c} \\
{[\mathbf{U S D} / \mathbf{G J}]}\end{array}$ \\
\hline 10 & 2.77 & 435.07 & 102.30 & -1960.35 & 541.20 & 3.72 & 6.88 \\
11 & 2.77 & 270.00 & 101.30 & -2143.67 & 296.45 & 0.00 & 0.00 \\
1 AT & 1.64 & 307.84 & 101.43 & 461.66 & 208.75 & 2.60 & 12.46 \\
1 ATg & 1.64 & 246.29 & 91.42 & 324.52 & 106.76 & 1.33 & 12.46 \\
1 ATf & 1.64 & 178.30 & 81.01 & 183.24 & 29.12 & 0.36 & 12.46 \\
2 AT & 1.64 & 142.65 & 68.15 & 113.96 & 5.90 & 0.07 & 12.46 \\
3 AT & 1.64 & 142.77 & 170.38 & 114.19 & 5.96 & 0.17 & 29.03 \\
1 ORC & 0.72 & 272.84 & 675.85 & 633.29 & 169.27 & 3.24 & 19.11 \\
2 ORC & 0.72 & 202.37 & 22.53 & 513.72 & 69.79 & 1.33 & 19.11 \\
2 gORC & 0.72 & 65.00 & 22.53 & 301.64 & 31.18 & 0.60 & 19.11 \\
3 ORC & 0.72 & 65.00 & 22.53 & -87.53 & 2.35 & 0.04 & 19.11 \\
4 ORC & 0.72 & 65.31 & 675.85 & -86.47 & 2.93 & 0.16 & 54.83 \\
4 fORC & 0.72 & 194.20 & 675.85 & 181.72 & 50.17 & 0.20 & 4.02 \\
4 gORC & 0.72 & 194.20 & 675.85 & 477.95 & 124.68 & 1.59 & 12.75 \\
1A & 13.32 & 50.00 & 101.30 & 209.42 & 35.20 & 0.00 & 0.00 \\
1gA & 13.32 & 55.00 & 101.30 & 230.33 & 54.44 & 0.60 & 11.02 \\
2A & 13.32 & 57.72 & 101.30 & 241.72 & 66.59 & 1.74 & 26.10 \\
\hline
\end{tabular}

Table A2. Thermodynamic properties and cost rate at different point using Cyclohexane.

\begin{tabular}{cccccccc}
\hline Stream & $\begin{array}{c}\mathbf{F} \\
{[\mathbf{~ K g} / \mathbf{s}]}\end{array}$ & $\begin{array}{c}\mathbf{T} \\
{\left[{ }^{\circ} \mathbf{C}\right]}\end{array}$ & $\begin{array}{c}\mathbf{P} \\
{[\mathbf{k P a}]}\end{array}$ & $\begin{array}{c}\mathbf{h} \\
{[\mathbf{k J} / \mathbf{k g}]}\end{array}$ & $\begin{array}{c}\mathbf{E} \\
{[\mathbf{k W}]}\end{array}$ & $\dot{\mathbf{C}}$ & $\boldsymbol{c}$ \\
\hline 10 & 2.77 & 435.07 & 102.30 & -1960.35 & 541.20 & 3.77 & 6.97 \\
11 & 2.77 & 270 & 101.30 & -2143.67 & 296.45 & 0.00 & 0.00 \\
$1 \mathrm{AT}$ & 1.64 & 311.37 & 101.43 & 469.76 & 211.13 & 2.63 & 12.45 \\
1 ATg & 1.64 & 226.68 & 91.45 & 282.60 & 77.69 & 0.97 & 12.45 \\
1 ATf & 1.64 & 180.07 & 81.03 & 186.74 & 28.88 & 0.36 & 12.45 \\
$2 \mathrm{AT}$ & 1.64 & 146.18 & 68.15 & 120.70 & 6.57 & 0.08 & 12.45 \\
3 AT & 1.64 & 146.3 & 170.38 & 120.93 & 6.63 & 0.18 & 27.29 \\
1 ORC & 0.72 & 276.37 & 1845.97 & 722.20 & 176.45 & 3.35 & 18.97 \\
2 ORC & 0.72 & 206.82 & 61.53 & 594.42 & 74.88 & 1.42 & 18.97 \\
2 gORC & 0.72 & 65 & 61.53 & 333.74 & 28.55 & 0.54 & 18.97 \\
3 ORC & 0.72 & 65 & 61.53 & -33.18 & 2.53 & 0.05 & 18.97 \\
4 ORC & 0.72 & 65.92 & 1845.97 & -29.95 & 4.25 & 0.24 & 56.63 \\
4 fORC & 0.72 & 220.86 & 1845.97 & 355.64 & 76.10 & 0.30 & 3.94 \\
4 gORC & 0.72 & 220.86 & 1845.97 & 567.89 & 132.27 & 1.31 & 9.92 \\
1A & 13.32 & 50 & 101.30 & 209.42 & 31.76 & 0.00 & 0.00 \\
1gA & 13.32 & 55 & 101.30 & 230.33 & 49.12 & 0.55 & 11.12 \\
2A & 13.32 & 58.55 & 101.30 & 245.18 & 63.61 & 1.83 & 28.74 \\
\hline
\end{tabular}

Table A3. Exergy destroyed by Component, Exergy destruction costs and Difference of relative cost and exergo-economic factor by system component (Toluene).

\begin{tabular}{|c|c|c|c|c|c|c|c|c|}
\hline Component & $\begin{array}{c}\dot{E} x_{D} \\
{[k W]}\end{array}$ & $\begin{array}{c}\dot{\mathrm{C}}_{\mathrm{D}} \\
{[\mathrm{USD} / \mathrm{s}]}\end{array}$ & $\frac{\dot{\mathrm{C}}_{\mathrm{L}}}{[\mathrm{USD} / \mathrm{s}]}$ & $\frac{\mathrm{Z}_{\mathbf{K}}}{[\mathrm{USD} / \mathrm{s}]}$ & $r_{K}$ & $f_{K}$ & $C_{I}[\mathrm{USD} / \mathrm{GJ}]$ & $C_{P}[\mathrm{USD} / \mathrm{GJ}]$ \\
\hline ITC1 & 41.95 & 0.64 & 4.51 & $7.35 \cdot 10^{-4}$ & 0.44 & 0.53 & 15.21 & 11.97 \\
\hline B1 & 0.32 & 0.01 & - & $7.89 \cdot 10^{-5}$ & 34.54 & 0.84 & 47.50 & 1700.64 \\
\hline ITC2 & 36.53 & 0.45 & - & $3.74 \cdot 10^{-4}$ & 0.48 & 0.54 & 12.45 & 18.48 \\
\hline $\mathrm{T} 1$ & 13.89 & 0.27 & - & $2.00 \cdot 10^{-2}$ & 1.50 & 0.89 & 19.11 & 47.85 \\
\hline ITC3 & 36.05 & 1.99 & 3.65 & $3.79 \cdot 10^{-4}$ & 1.41 & 0.18 & 55.37 & 19.11 \\
\hline B2 & 0.169 & 0.08 & - & $7.92 \cdot 10^{-5}$ & 3.13 & 0.91 & 47.84 & 197.64 \\
\hline
\end{tabular}


Table A4. Exergy destroyed by Component, Exergy destruction costs and Difference of relative cost and exergo-economic factor by system component (Cyclohexane).

\begin{tabular}{ccccccccc}
\hline Component & $\begin{array}{c}\dot{\mathrm{Ex}}_{\mathrm{D}} \\
{[\mathbf{k W}]}\end{array}$ & $\begin{array}{c}\dot{\mathrm{C}}_{\mathrm{D}} \\
{[\mathrm{USD} / \mathrm{s}]}\end{array}$ & $\begin{array}{c}\dot{\mathrm{C}}_{\mathrm{L}} \\
{[\mathrm{USD} / \mathbf{s}]}\end{array}$ & $\begin{array}{c}\mathrm{Z}_{\mathrm{K}} \\
{[\mathrm{USD} / \mathrm{s}]}\end{array}$ & $r_{K}$ & $f_{K}$ & $\boldsymbol{C}_{\boldsymbol{I}}[\mathrm{USD} / \mathrm{G}]$ & $\boldsymbol{C}_{\boldsymbol{P}}[\mathrm{USD} / \mathrm{GJ}]$ \\
\hline ITC1 & 40.25 & 0.62 & 4.56 & $7.43 \cdot 10^{-4}$ & 0.43 & 0.55 & 15.40 & 11.97 \\
B1 & 0.31 & 0.01 & - & $8.14 \cdot 10^{-4}$ & 34.28 & 0.85 & 47.47 & 1674.64 \\
ITC2 & 32.36 & 0.40 & - & $5.60 \cdot 10^{-4}$ & 0.45 & 0.58 & 12.45 & 18.04 \\
T1 & 14.04 & 0.27 & - & $2.23 \cdot 10^{-4}$ & 1.50 & 0.89 & 18.97 & 47.47 \\
ITC3 & 40.49 & 2.32 & 3.65 & $4.55 \cdot 10^{-4}$ & 1.52 & 0.16 & 57.39 & 18.97 \\
B2 & 0.50 & 0.02 & - & $8.76 \cdot 10^{-4}$ & 1.36 & 0.79 & 47.47 & 112.09 \\
\hline
\end{tabular}

\section{References}

1. Hung, T.C.; Shai, T.Y.; Wang, S.K. A review of organic rankine cycles (ORCs) for the recovery of low-grade waste heat. Energy 1997, 22, 661-667. [CrossRef]

2. Elzinga, D. Energy Technology Perspectives 2014: Harnessing Electricity's Potential; Int. Energy Agency: Paris, France, 2013; p. 382.

3. Hollander, J.M. The Energy-Environment Connection; Island Press: Wshington, DC, USA, 1992.

4. Pick, M.J. The renewable energy strategies of oil majors-From oil to energy? Energy Strategy Rev. 2019, 26, 100370. [CrossRef]

5. Østergaard, P.A.; Duic, N.; Noorollahi, Y.; Mikulcic, H.; Kalogirou, S. Sustainable development using renewable energy technology. Renew. Energy 2020, 146, 2430-2437. [CrossRef]

6. Li, Z.; Lu, Y.; Huang, Y.; Qian, G.; Chen, F.; Yu, X.; Roskilly, A. Comparison study of Trilateral Rankine Cycle, Organic Flash Cycle and basic Organic Rankine Cycle for low grade heat recovery. Energy Procedia 2017, 142, 1441-1447. [CrossRef]

7. Raghulnath, D.; Saravanan, K.; Mahendran, J.; kumar, M.R.; Lakshmanan, P. Analysis and optimization of organic Rankine cycle for IC engine waste heat recovery system. Mater. Today Proc. 2019, 1, 1-7. [CrossRef]

8. Armaroli, N.; Balzani, V. The Future of Energy Supply: Challenges and Opportunities. Angew. Chem. Int. Ed. 2007, 46, 52-66. [CrossRef] [PubMed]

9. Shi, L.; Shu, G.; Tian, H.; Deng, S. A review of modified Organic Rankine cycles (ORCs) for internal combustion engine waste heat recovery (ICE-WHR). Renew. Sustain. Energy Rev. 2018, 92, 95-110. [CrossRef]

10. Hoang, A.T. Waste heat recovery from diesel engines based on Organic Rankine Cycle. Appl. Energy 2018, 231, 138-166. [CrossRef]

11. Kwak, D.H.; Binns, M.; Kim, J.K. Integrated design and optimization of technologies for utilizing low grade heat in process industries. Appl. Energy 2014, 131, 307-322. [CrossRef]

12. Bao, J.; Zhao, L. A review of working fluid and expander selections for organic Rankine cycle. Renew. Sustain. Energy Rev. 2013, 24, 325-342. [CrossRef]

13. Linke, P.; Papadopoulos, A.I.; Seferlis, P. Systematic Methods for Working Fluid Selection and the Design, Integration and Control of Organic Rankine Cycles-A Review. Energies 2015, 8, 4755-4801. [CrossRef]

14. Larsen, U.; Pierobon, L.; Haglind, F.; Gabrielii, C. Design and optimisation of organic Rankine cycles for waste heat recovery in marine applications using the principles of natural selection. Energy 2013, 55, 803-812. [CrossRef]

15. Zhu, S.; Deng, K.; Qu, S. Energy and exergy analyses of a bottoming Rankine cycle for engine exhaust heat recovery. Energy 2013, 58, 448-457. [CrossRef]

16. Galindo, J.; Ruiz, S.; Dolz, V.; Royo-Pascual, L. Advanced exergy analysis for a bottoming organic rankine cycle coupled to an internal combustion engine. Energy Convers. Manag. 2016, 126, 217-227. [CrossRef]

17. Braimakis, K.; Karellas, S. Energetic optimization of regenerative Organic Rankine Cycle (ORC) configurations. Energy Convers. Manag. 2018, 159, 353-370. [CrossRef]

18. Peris, B.; Navarro-Esbrí, J.; Molés, F. Bottoming organic Rankine cycle configurations to increase Internal Combustion Engines power output from cooling water waste heat recovery. Appl. Therm. Eng. 2013, 61, 364-371. [CrossRef] 
19. Scaccabarozzi, R.; Tavano, M.; Invernizzi, C.M.; Martelli, E. Comparison of working fluids and cycle optimization for heat recovery ORCs from large internal combustion engines. Energy 2018, 158, 396-416. [CrossRef]

20. Tian, H.; Shu, G.; Wei, H.; Liang, X.; Liu, L. Fluids and parameters optimization for the organic Rankine cycles (ORCs) used in exhaust heat recovery of Internal Combustion Engine (ICE). Energy 2012, 47, 125-136. [CrossRef]

21. Wang, E.H.; Zhang, H.G.; Fan, B.Y.; Ouyang, M.G.; Zhao, Y.; Mu, Q.H. Study of working fluid selection of organic Rankine cycle (ORC) for engine waste heat recovery. Energy 2011, 36, 3406-3418. [CrossRef]

22. Andreasen, J.G.; Larsen, U.; Knudsen, T.; Pierobon, L.; Haglind, F. Selection and optimization of pure and mixed working fluids for low grade heat utilization using organic rankine cycles. Energy 2014, 73, 204-213. [CrossRef]

23. Seyedkavoosi, S.; Javan, S.; Kota, K. Exergy-based optimization of an organic Rankine cycle ( ORC ) for waste heat recovery from an internal combustion engine (ICE ). Appl. Therm. Eng. 2017, 126, 447-457. [CrossRef]

24. Yang, M.H.; Yeh, R.H. Thermodynamic and economic performances optimization of an organic Rankine cycle system utilizing exhaust gas of a large marine diesel engine. Appl. Energy 2015, 149, 1-12. [CrossRef]

25. Yang, M.H.; Yeh, R.H. Thermo-economic optimization of an organic Rankine cycle system for large marine diesel engine waste heat recovery. Energy 2015, 82, 256-268. [CrossRef]

26. Milani, S.M.; Saray, R.K.; Najafi, M. Exergo-economic analysis of different power-cycle configurations driven by heat recovery of a gas engine. Energy Convers. Manag. 2019, 186, 103-119. [CrossRef]

27. Quoilin, S.; Declaye, S.; Tchanche, B.F.; Lemort, V. Thermo-economic optimization of waste heat recovery Organic Rankine Cycles. Appl. Therm. Eng. 2011, 31, 2885-2893. [CrossRef]

28. Imran, M.; Park, B.S.; Kim, H.J.; Lee, D.H.; Usman, M.; Heo, M. Thermo-economic optimization of Regenerative Organic Rankine Cycle for waste heat recovery applications. Energy Convers. Manag. 2014, 87, 107-118. [CrossRef]

29. Shengjun, Z.; Huaixin, W.; Tao, G. Performance comparison and parametric optimization of subcritical Organic Rankine Cycle (ORC) and transcritical power cycle system for low-temperature geothermal power generation. Appl. Energy 2011, 88, 2740-2754. [CrossRef]

30. Feng, Y.; Zhang, Y.; Li, B.; Yang, J.; Shi, Y. Comparison between regenerative organic Rankine cycle (RORC) and basic organic Rankine cycle (BORC) based on thermoeconomic multi-objective optimization considering exergy efficiency and levelized energy cost (LEC). Energy Convers. Manag. 2015, 96, 58-71. [CrossRef]

31. Le, V.L.; Kheiri, A.; Feidt, M.; Pelloux-Prayer, S. Thermodynamic and economic optimizations of a waste heat to power plant driven by a subcritical ORC (Organic Rankine Cycle) using pure or zeotropic working fluid. Energy 2014, 78, 622-638. [CrossRef]

32. Chen, T.; Zhuge, W.; Zhang, Y.; Zhang, L. A novel cascade organic Rankine cycle (ORC) system for waste heat recovery of truck diesel engines. Energy Convers. Manag. 2017, 138, 210-223. [CrossRef]

33. Hou, G.; Bi, S.; Lin, M.; Zhang, J.; Xu, J. Minimum variance control of organic Rankine cycle based waste heat recovery. Energy Convers. Manag. 2014, 86, 576-586. [CrossRef]

34. Xi, H.; Li, M.J.; Xu, C.; He, Y.L. Parametric optimization of regenerative organic Rankine cycle (ORC) for low grade waste heat recovery using genetic algorithm. Energy 2013, 58, 473-482. [CrossRef]

35. Schuster, A.; Karellas, S.; Kakaras, E.; Spliethoff, H. Energetic and economic investigation of Organic Rankine Cycle applications. Appl. Therm. Eng. 2009, 29, 1809-1817. [CrossRef]

36. Rahbar, K.; Mahmoud, S.; Al-Dadah, R.K.; Moazami, N.; Mirhadizadeh, S.A. Review of organic Rankine cycle for small-scale applications. Energy Convers. Manag. 2017, 134, 135-155. [CrossRef]

37. Vivian, J.; Manente, G.; Lazzaretto, A. A general framework to select working fluid and configuration of ORCs for low-to-medium temperature heat sources. Appl. Energy 2015, 156, 727-746. [CrossRef]

38. Shu, G.; Li, X.; Tian, H.; Liang, X.; Wei, H.; Wang, X. Alkanes as working fluids for high-temperature exhaust heat recovery of diesel engine using organic Rankine cycle. Appl. Energy 2014, 119, 204-217. [CrossRef]

39. United Nations Environment Progamme UNEP. Montreal Protocol on Substances that Deplete the Ozone Layer. 1987. Available online: www.unep.org (accessed on 21 June 2019).

40. UNFCCC. Text of the Kyoto Protocol. Available online: https://unfccc.int/kyoto-protocol-html-version (accessed on 10 July 2019).

41. Song, J.; Song, Y.; Gu, C.w. Thermodynamic analysis and performance optimization of an Organic Rankine Cycle (ORC) waste heat recovery system for marine diesel engines. Energy 2015, 82, 976-985. [CrossRef] 
42. Kölsch, B.; Radulovic, J. Utilisation of diesel engine waste heat by Organic Rankine Cycle. Appl. Therm. Eng. 2015, 78, 437-448. [CrossRef]

43. Neto, R.d.; Sotomonte, C.A.R.; Coronado, C.J.R.; Nascimento, M. Technical and economic analyses of waste heat energy recovery from internal combustion engines by the Organic Rankine Cycle. Energy Convers. Manag. 2016, 129, 168-179. [CrossRef]

44. Grelet, V.; Reiche, T.; Lemort, V.; Nadri, M.; Dufour, P. Transient performance evaluation of waste heat recovery rankine cycle based system for heavy duty trucks. Appl. Energy 2016, 165, 878-892. [CrossRef]

45. Sung, T.; Kim, K.C. Thermodynamic analysis of a novel dual-loop organic Rankine cycle for engine waste heat and LNG cold. Appl. Therm. Eng. 2016, 100, 1031-1041. [CrossRef]

46. Michos, C.N.; Lion, S.; Vlaskos, I.; Taccani, R. Analysis of the backpressure effect of an Organic Rankine Cycle (ORC) evaporator on the exhaust line of a turbocharged heavy duty diesel power generator for marine applications. Energy Convers. Manag. 2017, 132, 347-360. [CrossRef]

47. Valencia, G.; Alvarez, J.N.; Duarte, J. Multiobjective Optimization of a Plate Heat Exchanger in a Waste Heat Recovery Organic Rankine Cycle System for Natural Gas Engines. Entropy 2019, 21, 655. [CrossRef]

48. Valencia, G.; Fontalvo, A.; Cárdenas, Y.; Duarte, J.; Isaza, C. Energy and Exergy Analysis of Different Exhaust Waste Heat Recovery Systems for Natural Gas Engine Based on ORC. Energies 2019, 12, 2378. [CrossRef]

49. Wang, E.; Yu, Z.; Zhang, H.; Yang, F. A regenerative supercritical-subcritical dual-loop organic Rankine cycle system for energy recovery from the waste heat of internal combustion engines. Appl. Energy 2017, 190, 574-590. [CrossRef]

50. Shams Ghoreishi, S.M.; Akbari Vakilabadi, M.; Bidi, M.; Khoeini Poorfar, A.; Sadeghzadeh, M.; Ahmadi, M.H.; Ming, T. Analysis, economical and technical enhancement of an organic Rankine cycle recovering waste heat from an exhaust gas stream. Energy Sci. Eng. 2019, 7, 230-254. [CrossRef]

51. Bejan, A.; Tsatsaronis, G.; Moran, M.J. Thermal Design and Optimization; John Wiley \& Sons: Hoboken, NJ, USA, 1996.

52. El-emam, R.S.; Dincer, I. Exergy and exergoeconomic analyses and optimization of geothermal organic Rankine cycle. Appl. Therm. Eng. 2013, 59, 435-444. [CrossRef]

53. Calise, F.; Capuozzo, C.; Carotenuto, A.; Vanoli, L. Thermoeconomic analysis and off-design performance of an organic Rankine cycle powered by medium-temperature heat sources. Sol. Energy 2014, 103, 595-609. [CrossRef]

54. Zare, V. A comparative exergoeconomic analysis of different ORC configurations for binary geothermal power plants. Energy Convers. Manag. 2015, 105, 127-138. [CrossRef]

55. Voros, N.G.; Kiranoudis, C.T.; Maroulis, Z.B. Solar energy exploitation for reverse osmosis desalination plants. Desalination 1998, 115, 83-101. [CrossRef]

56. Valencia, G.; Duarte, J.; Isaza-Roldan, C. Thermoeconomic Analysis of Different Exhaust Waste-Heat Recovery Systems for Natural Gas Engine Based on ORC. Appl. Sci. 2019, 9, 4017. [CrossRef]

57. Tsatsaronis, G. Application of Thermoeconomics to the Design and Synthesis of Energy Plants. In Exergy, Energy System Analysis and Optimization - Volume II; Frangopoulos, C., Ed.; EOLSS Publications: Paris, France, 2006; pp. 162-174.

58. Warren, S.; Junior, S.; Daniel, L. Product and Process Design Principles: Synthesis, Analysis, and Evaluation; John Wiley \& Sons: Hoboken, NJ, USA, 2013.

59. Val, C.d.; Silva, J.; Junior, S.d. Deep Water Cooled ORC for Offshore Floating Oil Platform Applications. Int. J. Thermodyn. 2017, 20, 229-237. [CrossRef]

(C) 2019 by the authors. Licensee MDPI, Basel, Switzerland. This article is an open access article distributed under the terms and conditions of the Creative Commons Attribution (CC BY) license (http://creativecommons.org/licenses/by/4.0/). 